\title{
Albicidin Pathotoxin Produced by Xanthomonas albilineans Is Encoded by Three Large PKS and NRPS Genes Present in a Gene Cluster Also Containing Several Putative Modifying, Regulatory, and Resistance Genes
}

\author{
Monique Royer, ${ }^{1}$ Laurent Costet, ${ }^{1}$ Eric Vivien, ${ }^{1}$ Martine Bes, ${ }^{1}$ Arnaud Cousin, ${ }^{1}$ Anne Damais, ${ }^{1}$ Isabelle \\ Pieretti, ${ }^{1}$ Alexandre Savin, ${ }^{1}$ Sandrine Megessier, ${ }^{1}$ Magali Viard, ${ }^{1}$ Roger Frutos, ${ }^{1}$ Dean W. Gabriel, ${ }^{2}$ and \\ Philippe C. Rott ${ }^{1}$ \\ 1UMR 385 CIRAD/ENSAM/INRA Biologie et Génétique des Interactions Plante-Parasite, Centre de Coopération \\ Internationale en Recherche Agronomique pour le Développement, Campus International de Baillarguet, TA 41/K, \\ 34398 Montpellier Cedex 5, France; ${ }^{2}$ Department of Plant Pathology, University of Florida, Gainesville 32611, U.S.A.
}

Submitted 16 May 2003. Accepted 21 November 2003.

\begin{abstract}
Xanthomonas albilineans, which causes leaf scald disease of sugarcane, produces a highly potent pathotoxin called albicidin. We report here sequencing and homology analysis of the major gene cluster, XALB1 $(55,839 \mathrm{bp})$, and a second, smaller region, XALB2 $(2,986$ bp), involved in albicidin biosynthesis. XALB1 contains 20 open reading frames, including i) three large genes with a modular architecture characteristic of polyketide synthases (PKSs) and nonribosomal peptide synthases (NRPSs) and ii) several putative modifying, regulatory, and resistance genes. Sequencing and complementation studies of six albicidin-defective mutants enabled us to confirm the involvement of the three PKS and NRPS genes encoded by XALB1 in albicidin production. XALB2 contains only one gene that is required for post-translational activation of PKS and NRPS enzymes, confirming the involvement of these enzymes in albicidin biosynthesis. In silico analysis of these three PKS or NRPS enzymes allowed us to propose a model for the albicidin backbone assembly and to gain insight into the structural features of this pathotoxin. This is the first description of a complete mixed PKS-NRPS gene cluster for toxin production in the genus Xanthomonas.
\end{abstract}

Additional keyword: antibiotic.

Xanthomonas albilineans is a systemic, xylem-invading pathogen that causes leaf scald disease of sugarcane (interspecific hybrids of Saccharum spp.) (Ricaud and Ryan 1989; Rott and Davis 2000). Leaf scald symptoms include chlorosis, necrosis, rapid wilting, and plant death. Chlorosis-inducing strains of the pathogen produce several toxic compounds. The major toxic component, named albicidin, inhibits chloroplast DNA replication, resulting in blocked chloroplast differentiation and chlorotic leaf streaks that are characteristic of the disease (Birch and Patil 1983, 1985b, 1987a,b). Several studies established that albicidin plays a key role in pathogenesis and especially in the development of disease symptoms (Birch

Corresponding author: Philippe Rott; Telephone: (33) 4996248 34; Fax: (33) 4996248 48; E-mail: philippe.rott@cirad.fr
2001; Wall and Birch 1997; Zhang and Birch 1997; Zhang et al. 1999). Additionally, albicidin inhibits prokaryotic DNA replication and is bactericidal to a range of gram-positive and gram-negative bacteria (Birch and Patil 1985a). Therefore, albicidin also is of interest as a potential clinical antibiotic (Birch and Patil 1985a).

Low yields of albicidin production by $X$. albilineans $(0.2$ $\mathrm{mg}$ of purified toxin per liter of culture) (Birch and Patil 1985b) have slowed studies into the chemical structure of the toxin, into the production of albicidin during disease progress, and into its potential therapeutic applications. Although the chemical structure of albicidin remains unknown, the following chemical characteristics were determined with $X$. albilineans strain LS2 from Hawaii (Birch and Patil 1985a,b): i) partial characterization of albicidin obtained by proton and ${ }^{13} \mathrm{C}$ nuclear magnetic resonance (NMR) spectroscopy suggested that the compound has several aromatic rings and approximately 38 carbon atoms; ii) analyses by mass spectroscopy indicated that the molecular weight of albicidin is approximately 842 and that the compound contains at least one carboxyl (COOH) group; iii) albicidin is soluble in methanol, tetrahydrofuran, dimethyl sulfoxide, and $95 \%$ acetone, sparingly soluble in water and acetonitrile, and essentially insoluble in less polar solvents; iv) spot tests with common spray reagents (Stahl 1969) gave reactions typical of acid and phenol groups; and $\mathrm{v}$ ) inhibitory activity of albicidin was undiminished after $3 \mathrm{~h}$ at $37^{\circ} \mathrm{C}$ with pronase at $50 \mu \mathrm{g} / \mathrm{ml}^{-1}$.

Two similar mutagenesis and complementation studies have been conducted to identify the genetic basis of albicidin production in X. albilineans strains isolated in two different geographical locations, Queensland and Florida. One study with $X$. albilineans strain LS155 from Queensland revealed that genes for albicidin biosynthesis and resistance span at least 69 kb (Wall and Birch 1997). Subsequently, three genes required for albicidin biosynthesis were identified, cloned, and sequenced from two Queensland strains of $X$. albilineans (LS155 and Xa13): $x a b A, x a b B$, and $x a b C$. The $x a b B$ gene encodes a large protein with a modular architecture indicative of a multifunctional polyketide synthase (PKS) linked to a nonribosomal peptide synthase (NRPS) (Huang et al. 2001). The $x a b C$ gene, located immediately downstream from $x a b B$, en- 
codes an S-adenosyl-L-methionine-dependent $O$-methyltransferase (Huang et al. 2000a). The $x a b A$ gene, located in another region of the genome, encodes a phosphopantetheinyl transferase required for post-translational activation of PKS and NRPS enzymes (Huang et al. 2000b).

A second study with $X$. albilineans strain Xa23R1 from Florida revealed that at least two gene clusters, one spanning more than $48 \mathrm{~kb}$, are involved in albicidin production (Rott et al. 1996). This conclusion was based on the following data: i) $50 \mathrm{Xa23R} 1$ mutants defective in albicidin production were isolated; ii) two overlapping DNA inserts from an Xa23R1 genomic library of approximately 47 and $41 \mathrm{~kb}$ from clones pALB540 and pALB571, respectively, complemented 45 of the mutants; and iii) 5 remaining mutants were not complemented by either pALB540 or pALB571.

NRPS and PKS enzymes are large, multifunctional enzymes organized into modules individually responsible for one elongation step of the growing polypeptide or polyketide chain (Cane and Walsh 1999). An NRPS module consists of three domains: the adenylation domain (A) that activates an amino acid monomer, a peptidyl carrier protein (PCP) that tethers the growing polypeptide, and a condensation domain (C) that catalyses the formation of the peptide bond between the activated amino acid and the growing polypeptide. Similarly, a PKS module consists of three domains: the acyltransferase domain (AT) that activates an acyl-CoA monomer; the acyl carrier protein domain (ACP) that tethers the growing polyketide, and the ketosynthase domain (KS) that catalyses the formation of a bond between the activated monomer and the growing polyketide. In addition to the basic subset of core domains, each NRPS or PKS system also has i) a domain responsible for the initiation of chain assembly by loading of a starter unit onto the first PKS/NRPS module and ii) a chainterminating thioesterase (TE) domain, most often found fused to the last module, that is responsible for detachment of the mature polyketide or polypeptide chain (Cane and Walsh 1999). The adenylation and acyltransferase domains are gatekeepers for the biosynthesis of the polypeptide and the polyketide, respectively, because of strict and high specificity for their cognate substrates.

The NRPS substrate binding pockets are so highly specific for their substrates that predictive models based upon consensus signature motifs for known substrates have been determined. Based on sequence analysis of 160 known prokaryotic A domains and on the crystal structure of the substrate binding pocket of the phenylalanine A domain of gramicidin $\mathrm{S}$ synthase from Brevibacillus brevis, two models have been published to predict the amino acid substrate which is recognized by an unknown NRPS A domain (Challis et al. 2000; Stachelhaus et al. 1999). The model defined by Stachelhaus and associates (1999) identifies a group of 10 residues within pockets that encode amino acid specificity. The model defined by Challis and associates (2000) identifies eight of the same residues defined by Stachelhaus and associates (1999), excluding the tenth residue, which is involved in binding the carboxyl group of an amino acid and the ninth residue. In addition, based on the crystal structure of an aryl acid-activating domain, May and associates (2002) identified a group of 10 residues within
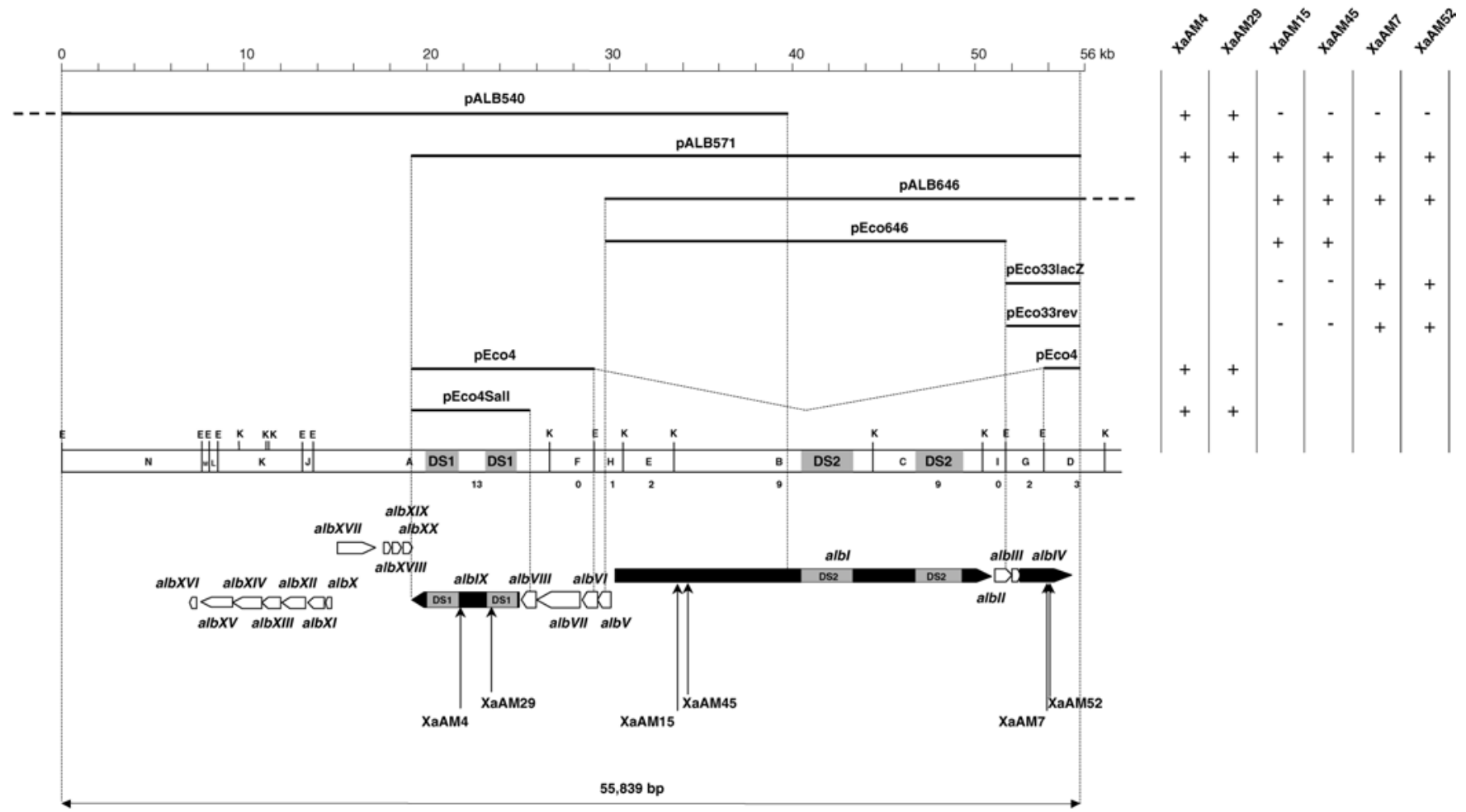

Fig. 1. Physical map and genetic organization of the DNA region containing the gene cluster XALB1 involved in albicidin production. Restriction map: E and $\mathrm{K}$ are restriction sites for EcoRI and KpnI, respectively. Rectangular boxes represent DNA fragments labeled A through N. The number below each rectangular box is the number of the Tn5-gusA insertion sites previously located in each DNA fragment in 39 albicidin-defective mutants complemented by pALB571 (Rott et al. 1996). The DNA inserts carried by plasmids pALB540, pALB571, pALB646, pEco646, pEco33lacZ, pEco33rev, pEco4, and pEco4SalI are represented by bars above the physical map. The location and direction of the 20 open reading frames (ORFs) identified in the XALB1 gene cluster are shown by thick arrows. The three polyketide synthase and nonribosomal peptide synthase genes are shown by black and thick arrows. Position of Tn 5 insertional sites of six albicidin-defective mutants determined by sequencing are indicated by vertical arrows. Shaded regions in the physical map and white boxes in ORFs albl and $a l b I X$ represent the two internal duplicated DNA regions of XALB1 designated DS1 and DS2. Results of complementation studies are summarized in the table at the right of the figure; $+=$ restoration of albicidin production and $-=$ no restoration of albicidin production. All experiments were performed at least in duplicate with 2 to 12 exconjugants. 
pockets that encode aryl acid specificity. A combination of different modules, their order, and the arrangement of the different auxiliary domains can be used to successfully predict the final structure of the synthesized polyketide or polypeptide.

We report here DNA sequencing of the major gene cluster XALB1 present in the two overlapping DNA inserts of clones pALB540 and pALB571. Reading frame analysis and homology analysis revealed the presence in XALB1 of 20 open reading frames (ORFs) designated albI to albXX. Complementation studies of six mutants defective in albicidin production enabled us to confirm the involvement in albicidin production of three of these genes (albI, albIV, and albIX) which encode three large PKS and NRPS enzymes. Alignment of these three PKS or NRPS enzymes encoded by XALB 1 allowed us to propose a model for the albicidin backbone assembly and to partially predict the structure of albicidin. We also report cloning and DNA sequencing of a second region of the genome involved in albicidin production (XALB2) which contains only one gene (albXXI) which is $99 \%$ identical to $x a b A$ and which is required for activation of PKS and NRPS enzymes.

Table 1. Bacterial strains, plasmids, and DNA fragment used in this study

\begin{tabular}{|c|c|c|}
\hline Strain or plasmid & Relevant characteristics ${ }^{a}$ & Reference or source \\
\hline \multicolumn{3}{|l|}{ Strains } \\
\hline \multicolumn{3}{|l|}{ Escherichia coli } \\
\hline DH5 $\alpha$ & $\begin{array}{l}\text { F-f80dlacZAM15 } \Delta\left(\text { lacZYA-argF)U169 deoR recA1 endA1 hsdR17( } \mathrm{r}_{\mathrm{k}}{ }^{-} \mathrm{m}_{\mathrm{k}}{ }^{+}\right) \\
\text {supE44 thi-1 gyrA96 relA1 }\end{array}$ & Gibco-BRL \\
\hline \multicolumn{3}{|c|}{ Xanthomonas albilineans } \\
\hline Хa23 & Wild type from sugarcane (Florida) & Rott et al. 1996 \\
\hline Xa23R1 & Spontaneous Rif $^{\mathrm{T}}$ derivative of $\mathrm{Xa} 23$ & Rott et al. 1996 \\
\hline $8 \mathrm{XaAM}$ strains & Xa23R1::Tn5-gusA, $\mathrm{Km}^{\mathrm{r}}, \mathrm{Rif}^{\mathrm{r}}, \mathrm{Tox}^{-}$ & Rott et al. 1996 \\
\hline LS156 & LS155-xabA::Rn5, $\mathrm{Km}^{\mathrm{r}}, \mathrm{St}^{\mathrm{r}}, \mathrm{Tox}^{-}$ & Huang et al. 2000b \\
\hline LS156R1 & Spontaneous $\mathrm{Rif}^{\mathrm{T}}$ derivative of LS156 & Rott et al. 1996 \\
\hline LS157 & LS155-xabB::Tn5-xabB, $\mathrm{Km}^{\mathrm{r}}, \mathrm{St}^{\mathrm{r}}, \mathrm{Tox}^{-}$ & Huang et al. 2001 \\
\hline LS157R1 & Spontaneous Rif ${ }^{\mathrm{T}}$ derivative of LS157 & Rott et al. 1996 \\
\hline \multicolumn{3}{|c|}{ 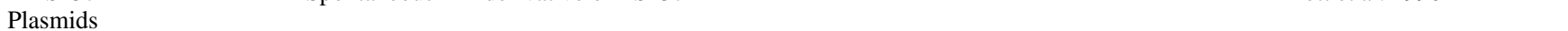 } \\
\hline pBR325 & $\mathrm{Tc}^{\mathrm{r}}, \mathrm{Ap}^{\mathrm{r}}, \mathrm{Cm}^{\mathrm{r}}$ & Gibco-BRL \\
\hline $\mathrm{pBCKS}(+)$ & $\mathrm{Cm}^{\mathrm{r}}$ & Stratagene \\
\hline pBluescript II KS(+) & $A p^{r}$ & Stratagene \\
\hline pRK2073 & pRK2013 derivative, $\mathrm{Km}^{\mathrm{s}}(n p t: \mathrm{Tn} 7), \mathrm{Sp}^{\mathrm{r}}, \mathrm{Tra}^{+}$, helper plasmid & Leong et al. 1982 \\
\hline pUFR043 & $\mathrm{IncW} \mathrm{Mob}^{+} \mathrm{LacZ} \alpha, \mathrm{Gm}^{\mathrm{r}}, \mathrm{Km}^{\mathrm{r}}, \mathrm{Cos}$ & De Feyter and Gabriel 1991 \\
\hline pALB540 & 47-kb insert from Xa23R1 in pUFR043, $\mathrm{Gm}^{\mathrm{r}}, \mathrm{Km}^{\mathrm{r}}$ & Rott et al. 1996 \\
\hline pALB571 & 36.8-kb insert from Xa23R1 in pUFR043, $\mathrm{Gm}^{\mathrm{r}}, \mathrm{Km}^{\mathrm{r}}$ & Rott et al. 1996 \\
\hline pAM15.1 & 24-kb EcoRI fragment carrying Tn5 and flanking sequences of mutant XaAM15 in & \\
\hline \multirow[t]{2}{*}{ pAM45.1 } & $\begin{array}{l}\text { pBR325, } \mathrm{Km}^{1}, \mathrm{Tc}^{1}, \mathrm{Ap}^{1}, \mathrm{Cm}^{1} \\
12-\mathrm{kb} \text { EcoRI fragment carrying Tn } 5 \text { and flanking sequences of mutant XaAM45 in }\end{array}$ & Rott et al. 1996 \\
\hline & pBR325, $\mathrm{Km}^{\mathrm{r}}, \mathrm{Tc}^{\mathrm{r}}, \mathrm{Ap}^{\mathrm{r}}, \mathrm{Cm}^{\mathrm{r}}$ & Rott et al. 1996 \\
\hline pALB646 & 37-kb insert from Xa23R1 in pUFR043, $\mathrm{Gm}^{\mathrm{r}}, \mathrm{Km}^{\mathrm{r}}$ & This study \\
\hline pEco646 & $22-\mathrm{kb}$ insert from pALB646 in pUFR043, $\mathrm{Gm}^{\mathrm{r}}, \mathrm{Km}^{\mathrm{r}}$ & This study \\
\hline pEco4 & 9.9- and $2.2-\mathrm{kb}$ inserts from pALB571 in pUFR043, $\mathrm{Gm}^{\mathrm{r}}, \mathrm{Km}^{\mathrm{r}}$ & This study \\
\hline pEco4SalI & 6.4-kb insert from pALB571 in pUFR043, $\mathrm{Gm}^{\mathrm{r}}, \mathrm{Km}^{\mathrm{r}}$ & This study \\
\hline pEco33lacZ & 4.1-kb insert from pALB571 in pUFR043, $\mathrm{Gm}^{\mathrm{r}}, \mathrm{Km}^{\mathrm{r}}$ & This study \\
\hline pEco33rev & 4.1-kb insert from pALB571 in pUFR043, $\mathrm{Gm}^{\mathrm{r}}, \mathrm{Km}^{\mathrm{r}}$ & This study \\
\hline pALB389 & 37-kb insert from Xa23R1 in pUFR043, $\mathrm{Gm}^{\mathrm{r}}, \mathrm{Km}^{\mathrm{r}}$ & This study \\
\hline pAC389.1 & 2.9-kb insert from pALB389 in pUFR043, $\mathrm{Gm}^{\mathrm{r}}, \mathrm{Km}^{\mathrm{r}}$ & This study \\
\hline $\mathrm{pBC} / \mathrm{A}^{\prime}$ & 7.5-kb KpnI fragment carrying a part of fragment A from pALB571 in pBCKS $(+), \mathrm{Cm}^{\mathrm{r}}$ & This study \\
\hline $\mathrm{pBC} / \mathrm{AF}$ & 15.2-kb EcoRI fragment carrying fragments A and $\mathrm{F}$ from pALB540 in pBCKS $(+), \mathrm{Cm}^{\mathrm{r}}$ & This study \\
\hline $\mathrm{pBC} / \mathrm{B}$ & 11.0-kb KpnI fragment B from pALB571 in pBCKS $(+), \mathrm{Cm}^{\mathrm{r}}$ & This study \\
\hline $\mathrm{pBC} / \mathrm{C}$ & 6.0-kb KpnI fragment C from pALB571 in pBCKS $(+), \mathrm{Cm}^{\mathrm{r}}$ & This study \\
\hline $\mathrm{pBC} / \mathrm{E}$ & 2.8-kb KpnI fragment E from pALB571 in pBCKS $(+), \mathrm{Cm}^{\mathrm{r}}$ & This study \\
\hline $\mathrm{pBC} / \mathrm{F}$ & 2.5-kb KpnI-EcoRI fragment $\mathrm{F}$ from pALB571 in pBCKS $(+), \mathrm{Cm}^{\mathrm{r}}$ & This study \\
\hline $\mathrm{pBC} / \mathrm{G}$ & $1.9-\mathrm{kb}$ EcoRI fragment G from pALB571 in pBCKS $(+), \mathrm{Cm}^{\mathrm{r}}$ & This study \\
\hline $\mathrm{pBC} / \mathrm{I}$ & 1.4-kb KpnI-EcoRI fragment I from pALB571 in pBCKS $(+), \mathrm{Cm}^{\mathrm{r}}$ & This study \\
\hline $\mathrm{pBC} / \mathrm{J}$ & $0.6-\mathrm{kb} E c o R I$ fragment $\mathrm{J}$ from pALB540 in pBCKS $(+), \mathrm{Cm}^{\mathrm{r}}$ & This study \\
\hline $\mathrm{pBC} / \mathrm{K}$ & 4.7-kb EcoRI fragment $\mathrm{K}$ from pALB540 in pBCKS $(+), \mathrm{Cm}^{\mathrm{r}}$ & This study \\
\hline $\mathrm{pBC} / \mathrm{L}$ & 0.4-kb EcoRI fragment $\mathrm{L}$ from pALB540 in pBCKS $(+), \mathrm{Cm}^{\mathrm{r}}$ & This study \\
\hline $\mathrm{pBC} / \mathrm{N}$ & 7.7-kb EcoRI fragment $\mathrm{N}$ from pALB540 in pBCKS $(+), \mathrm{Cm}^{\mathrm{r}}$ & This study \\
\hline pUFR043/D' & 2.2-kb EcoRI-Sau3AI fragment carrying a part of fragment D from pALB571 in pUFR043 & This study \\
\hline pAM4 & $\begin{array}{l}\text { 12-kb EcoRI fragment carrying Tn5 and flanking sequences of mutant XaAM4 in } \\
\text { pBluescript II KS }(+), \mathrm{Km}^{\mathrm{r}}, \mathrm{Ap}^{\mathrm{r}}\end{array}$ & This study \\
\hline \multirow[t]{2}{*}{ pAM7 } & 6-kb EcoRI fragment carrying Tn5 and flanking sequences of mutant XaAM7 in & 1 ins stuuy \\
\hline & pBluescript II KS (+), Km ${ }^{\mathrm{r}}, \mathrm{Ap}^{\mathrm{r}}$ & This study \\
\hline \multirow[t]{2}{*}{ pAM10 } & 7-kb EcoRI fragment carrying Tn5 and flanking sequences of mutant XaAM10 in & \\
\hline & pBluescript II KS (+), $\mathrm{Km}^{\mathrm{r}}, \mathrm{Ap}^{\mathrm{r}}$ & This study \\
\hline \multirow[t]{2}{*}{ pAM29 } & 10-kb EcoRI fragment carrying Tn5 and flanking sequences of mutant XaAM29 in & \\
\hline & pBluescript II KS (+), $\mathrm{Km}^{\mathrm{r}}, \mathrm{Ap}^{\mathrm{r}}$ & This study \\
\hline \multirow[t]{2}{*}{ pAM37 } & 6-kb EcoRI fragment carrying Tn5 and flanking sequences of mutant XaAM37 in & \\
\hline & $\mathrm{pBR} 325, \mathrm{Km}^{\mathrm{r}}, \mathrm{Tc}^{\mathrm{r}}, \mathrm{Ap}^{\mathrm{r}}, \mathrm{Cm}^{\mathrm{r}}$ & This study \\
\hline \multirow[t]{2}{*}{ pAM52 } & 5-kb EcoRI fragment carrying Tn5 and flanking sequences of mutant XaAM52 in & \\
\hline & pBluescript II KS (+), Km, $\mathrm{Ap}^{\mathrm{r}}$ & This study \\
\hline \multicolumn{3}{|c|}{ Pв } \\
\hline PR37 & 1.1-kb HindIII-HindIII from pAM37 & This study \\
\hline
\end{tabular}

${ }^{\mathrm{a}} \mathrm{Ap}^{\mathrm{r}}, \mathrm{Cm}^{\mathrm{r}}, \mathrm{Gm}^{\mathrm{r}}, \mathrm{Km}^{\mathrm{r}}, \mathrm{Rif}^{\mathrm{r}}, \mathrm{Sp}^{\mathrm{r}}, \mathrm{St}^{\mathrm{r}}$, and $\mathrm{Tc}^{\mathrm{r}}=$ resistant to ampicillin, chloramphenicol, gentamycin, kanamycin, rifampicin, spectinomycin, streptomycin and tetracycline, respectively. Tox ${ }^{-}=$deficient in albicidin production. $\operatorname{Tn} 5$-gusA, $\operatorname{Tn} 5$-uidA1 $\mathrm{Km}^{\mathrm{r}} \mathrm{Tc}^{\mathrm{r}}$, forms transcriptional fusions. 


\section{RESULTS}

Sequencing of the double-stranded region from $X$. albilineans containing XALB1.

Both strands of a double-stranded region of 55,839 bp present in two overlapping DNA inserts of the clones pALB571 and pALB540 were sequenced (Fig. 1) (GenBank accession number AJ586576). This region, which complemented 45 of the 50 Xa23R1 mutants defective in albicidin production (Rott et al. 1996) (Table 1), contains the albicidin biosynthetic gene cluster XALB1.

\section{Homology analysis}

of proteins potentially encoded by XALB1.

Among the ORFs identified from the sequenced XALB1 gene cluster, $20 \mathrm{ORFs}$, designated $a l b I$ to $a l b X X$, potentially encode proteins similar to proteins from the GenBank database (Fig. 1). They include i) three large genes, albI, albIV, and albIX, encoding PKS or NRPS modules; and ii) several putative modifying, regulatory, and resistance genes (Table 2). Three of them are very similar to genes previously isolated from $X$. albilineans and described as involved in albicidin biosynthesis or in albicidin resistance: i) albI, which is very similar to $x a b B$, described as encoding a PKS-NRPS enzyme involved in albicidin biosynthesis (Huang et al. 2001); ii) albII, which is $100 \%$ identical to the $x a b C$ cistron, described downstream $x a b B$ as encoding a $S$-adenosyl-L-methionine $O$-methyltransferase involved in albicidin biosynthesis (Huang et al. 2000a); and iii) albXIV, which is $100 \%$ identical to $a l b F$, described in GenBank as encoding a putative albicidin efflux pump that confers high level of albicidin resistance in Escherichia coli (accession number AAL01877).

Table 2. Putative deduced functions of the open reading frames in the XALB1 gene cluster

\begin{tabular}{|c|c|c|c|c|c|c|}
\hline Protein & $\begin{array}{l}\text { No. of } \\
\text { amino } \\
\text { acids }\end{array}$ & Proposed function $^{\mathrm{a}}$ & $\begin{array}{l}\text { Sequence similarity } \\
\text { (protein, origin) }\end{array}$ & $\begin{array}{c}\text { Identity/ } \\
\text { similarity } \\
(\%)\end{array}$ & $\begin{array}{l}\text { Consensus } \\
\text { length }\end{array}$ & $\begin{array}{c}\text { GenBank } \\
\text { accession no. }\end{array}$ \\
\hline \multirow[t]{10}{*}{ AlbI } & 6,879 & Polyketide-peptide synthase & & & & \\
\hline & & PKS modules $\quad$ PKS domains & & & & \\
\hline & & AL ACP1 & $\begin{array}{l}\text { XabB, } \\
\text { Xanthomonas albilineans }\end{array}$ & $100 / 100$ & 730 & AAK 15074 \\
\hline & & KS1 KR ACP2 ACP3 & $\mathrm{XabB}, X$. albilineans & $100 / 100$ & 1,882 & AAK 15074 \\
\hline & & KS2 PCP1 & $\mathrm{XabB}, X$. albilineans & $100 / 100$ & 653 & AAK 15074 \\
\hline & & NRPS domains & & & & \\
\hline & & $\mathrm{C}$ A $\mathrm{PCP} 2$ & XabB, $X$. albilineans & $99 / 99$ & 1,046 & AAK 15074 \\
\hline & & C A PCP3 & NosA, Nostoc sp. & $29 / 43$ & 1,127 & AAF15891 \\
\hline & & $\mathrm{C}$ A PCP4 & XabB, $X$. albilineans & $95 / 96$ & 1,044 & AAK 15074 \\
\hline & & NRPS-4 & $\mathrm{XabB}, X$. albilineans & $100 / 100$ & 468 & AAK 15074 \\
\hline AlbII & 343 & $O$-methyltransferase & XabC, $X$. albilineans & $100 / 100$ & 343 & AAK 15075 \\
\hline AlbIII & 167 & Activation of alb genes transcription & ComA, Escherichia coli & $50 / 65$ & 135 & BAA 15452 \\
\hline \multirow[t]{4}{*}{ AlbIV } & 941 & Peptide synthase & & & & \\
\hline & & NRPS domains & & & & \\
\hline & & NRPS-5 & $\begin{array}{l}\text { BA3, } \\
\text { Bacillus licheniformis }\end{array}$ & $43 / 60$ & 441 & AAC06348 \\
\hline & & $N, O$-acyltransferase & $\begin{array}{l}\text { FeeH, } \\
\text { uncultured bacterium }\end{array}$ & $24 / 40$ & 123 & AAM97301 \\
\hline \multirow[t]{2}{*}{ AlbV } & 239 & No function (transposition) & $\begin{array}{l}\text { IS transposase, } \\
\text { Yersinia pestis }\end{array}$ & $47 / 66$ & 183 & $\mathrm{AAC} 82714$ \\
\hline & & & Thp, $X$. albilineans & $100 / 100$ & 239 & Huang et al. 2000a \\
\hline \multirow[t]{2}{*}{ AlbVI } & 286 & $O$-methyltransferase & $\mathrm{TcmP}$ & & & \\
\hline & & & Pasteurella multocida & $28 / 49$ & 132 & AAK03406 \\
\hline AlbVII & 765 & 4-hydroxybenzoate CoA ligase & $\begin{array}{l}\text { HbaA, Rhodopseudomonas } \\
\text { palustris }\end{array}$ & $31 / 48$ & 492 & AAA62604 \\
\hline AlbVIII & 330 & Regulation & $\begin{array}{l}\text { SyrP, } \\
\text { Pseudomonas syringae }\end{array}$ & $34 / 50$ & 306 & AAB 63253 \\
\hline \multirow[t]{3}{*}{ AlbIX } & 1,959 & $\begin{array}{l}\text { Peptide synthase } \\
\text { NRPS modules }\end{array}$ & & & & \\
\hline & & NRPS-6 & XabB,$X$. albilineans & $47 / 61$ & 608 & AAK15074 \\
\hline & & C A PCP7 & XabB,$X$. albilineans & $46 / 61$ & 1,110 & AAK 15074 \\
\hline AlbX & 83 & Unknown & $\begin{array}{l}\text { MbtH, Mycobacterium } \\
\text { tuberculosis }\end{array}$ & $45 / 66$ & 55 & CAB08480 \\
\hline AlbXI & 315 & Esterase & SyrC, $P$. syringae & $24 / 42$ & 93 & AAA85161 \\
\hline AlbXII & 451 & Unknown & BoxB, Azoarcus evansii & $38 / 53$ & 448 & AAK00599 \\
\hline AlbXIII & 317 & Unknown & $\begin{array}{l}\mathrm{Hp}, \\
\text { Caulobacter crescentus }^{\mathrm{b}}\end{array}$ & $29 / 41$ & 296 & AAK 25001 \\
\hline AlbXIV & 496 & Albicidin transporter & AlbF, $X$. albilineans & $100 / 100$ & 496 & AAL01877 \\
\hline AlbXV & 584 & Carbamoyl transferase & $\begin{array}{l}\mathrm{B} 1 \mathrm{mD}, \\
\text { Streptomyces verticillus }\end{array}$ & $33 / 46$ & 441 & AAG02370 \\
\hline AlbXVI & 88 & No function (transposition) & $\begin{array}{l}\text { OrfA, } \\
\text { Desulfovibrio vulgaris }\end{array}$ & $53 / 69$ & 54 & AAC03166 \\
\hline AlbXVII & 716 & Para-amino benzoate synthase & PABA synthase, S. griseus & $43 / 58$ & 699 & CAC22117 \\
\hline AlbXVIII & 137 & 4-amino-4-deoxychorismate lyase & ADCL, $P$. aeruginosa & $43 / 61$ & 105 & AAG06352 \\
\hline AlbXIX & 200 & Immunity against albicidin & McbG, E. coli & $25 / 40$ & 141 & CAA30724 \\
\hline AlbXX & 202 & 4-hydroxybenzoate synthetase & UbiC, E. coli & $26 / 40$ & 161 & CAA40681 \\
\hline
\end{tabular}

${ }^{a}$ Nonribosomal peptide synthase (NRPS) and polyketide synthase (PKS) domains are abbreviated as follows: A = adenylation, ACP $=$ acyl carrier protein, $\mathrm{AL}=$ acyl CoA ligase, $\mathrm{C}=$ condensation, $\mathrm{KR}=$ ketoreductase, $\mathrm{KS}=$ ketoacyl synthase, and $\mathrm{PCP}=$ peptidyl carrier protein. Underlined domain is likely inactive due to the lack of highly conserved motifs.

${ }^{\mathrm{b}} \mathrm{Hp}=$ hypothetical protein. 
Two large internal duplications, designated DS1 and DS2, are present in albIX and albI genes, respectively (Fig. 1). The two copies of the 1,736-bp DS1 duplicated sequence located in albIX differ by one nucleotide. The two copies of the 2,727bp DS2 duplicated sequence located in albI differ by $30 \mathrm{nu}-$ cleotides.

\section{Identification of albI, albIV, and albIX mutants.}

The Tn5-gusA insertion sites of 39 albicidin-defective mutants complemented by pALB571 previously were located in different EcoRI or KpnI DNA fragments of XALB1 by Southern blots (Rott et al. 1996) (Fig. 1, see number below each rectangular box). Further analyses revealed that the insertion sites of these $39 \mathrm{Tox}^{-}$mutants were located in albI, albIV, or albIX: i) the 20 insertions which previously were located in fragments $\mathrm{E}, \mathrm{B}$, or $\mathrm{C}$ were found to be internal to albI; ii) the 3 insertions which previously were located in fragment $\mathrm{D}$ were internal to albIV; iii) sequencing of the Tn 5 insertion site of the two mutants located in fragment $G$ revealed that they were located in $a l b I V$; iv) albicidin production was restored in the mutant located in fragment $\mathrm{H}$ by complementation with pEco646 (containing only albI and $825 \mathrm{bp}$ of the $1,032 \mathrm{bp}$ of albII) (Fig. 1), confirming that this mutant is located in albI; and v) the 13 insertions which previously were located in fragment $\mathrm{A}$ and which were complemented by pALB571 correspond, therefore, to albIX or albVIII mutants (most probably albIX mutants because albIX corresponds to $75 \%$ of the part of DNA fragment A present in pALB571).

\section{Complementation analysis \\ of six albI, albIV, or albIX mutants.}

Further complementation studies were performed with the following six $X$. albilineans Tox $^{-}$mutants which contain a single Tn5 insertion each: two albI mutants, XaAM15 and XaAM45, located at position 33,443 and 34,229, respectively; two albIV mutants, XaAM7 and XaAM52, located at position 53,704 and 53,915, respectively; and two albIX mutants, XaAM4 and XaAM29, located at position 21,653 and 23,444, respectively (Fig. 1). Previous complementation studies showed that XaAM7, XaAM15, XaAM45, and XaAM52 were complemented by pALB571 but not by pALB540; and that XaAM4 and XaAM29 were complemented by both cosmids (Rott et al. 1996).

The two albI mutants were complemented with cosmids pALB646 and pEco646. pALB646 contains a DNA insert of $41 \mathrm{~kb}$ cloned in reverse orientation of lac $Z$ promoter and starts at base pair 29,699 of XALB1 (497 bp upstream from the TTG of albI). pALB646 contains albI, albII, albIII, and albIV and the 12-kb unsequenced DNA region downstream from XALB1. pEco646 contains albI and the first $825 \mathrm{bp}$ of the 1,032 bp of albII. Transfer of pALB646 into XaAM15 and XaAM45 restored albicidin production, indicating that the promoter of albI is present in the $497 \mathrm{bp}$ upstream from the TTG of albI. Transfer of pEco646 into the two albI mutants XaAM15 and XaAM45 also restored albicidin production, confirming that albI was involved in albicidin production, and suggested that albI and albIV are not in the same operon.

The two albIV mutants were complemented with cosmids pEco33lacZ and pEco33rev. pEco33lacZ contains albIII and albIV in the forward orientation of the lac $Z$ promoter. pEco33rev contains the same DNA insert as pEco33lacZ but in the reverse orientation of the lacZ promoter. Transfer of pEco33lacZ and pEco33rev into the two albIV mutants XaAM7 and XaAM52 restored albicidin production. These results confirmed that $a l b I$ and $a l b I V$ are in two different operons and that $a l b I V$ is under the control of a promoter located in the $706 \mathrm{bp}$ preceding the GTG of albIV.

The two albIX mutants were complemented by cosmids pEco4 and pEco4SalI. pEco4 contains albVII, albVIII, and $\mathrm{a} l b I X$ in the reverse orientation of the $l a c Z$ promoter. pEco 4 also contains DNA fragment $\mathrm{D}^{\prime}$ formed by the last $1,593 \mathrm{bp}$ of the 2,823 bp of albIV plus the last 632 bp of XALB1 (Fig. 1). pEco4SalI contains albIX and the 545 bp upstream from albIX. Transfer of pEco4 and pEco4SalI into the two albIX mutants (XaAM4 and XaAM29) restored albicidin production, indicating that albIX is not expressed as part of an operon and that albIX is under the control of a promoter located in the 545 bp upstream albIX.
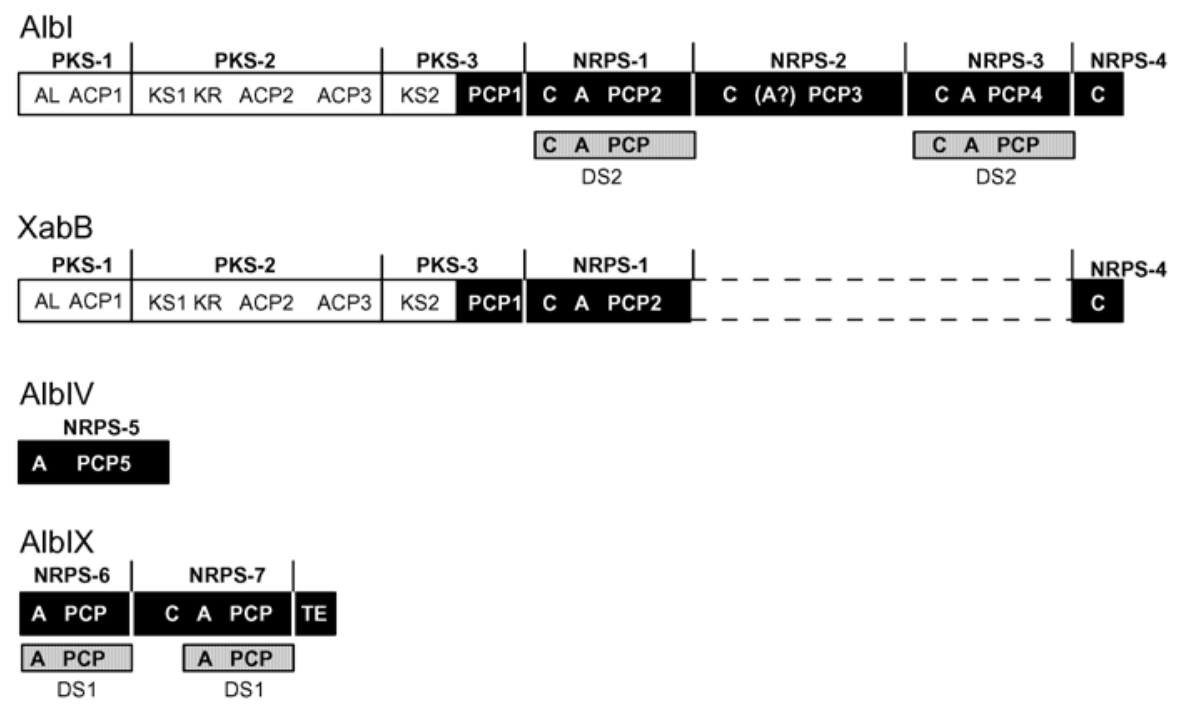

Fig. 2. Organization of the three polyketide synthase (PKS) modules and the seven nonribosomal peptide synthase (NRPS) modules identified in cluster XALB1, and comparison with the organization of XabB described in strain Xa13 from Australia (Huang et al. 2001). Dotted box corresponds to the deletion of NRPS-2 and NRPS-3 modules in XabB compared with AlbI. Shaded boxes correspond to duplicated sequences DS1 and DS2 located in AlbIX and AlbI, respectively. Abbreviations: $\mathrm{A}=$ adenylation, $\mathrm{ACP}=$ acyl carrier protein, $\mathrm{AL}=$ acyl-CoA ligase, $\mathrm{C}=\mathrm{condensation}, \mathrm{KR}=\beta$-ketoacyl reductase, $\mathrm{KS}=\beta$ ketoacyl synthase, NRPS = nonribosomal peptide synthase, $\mathrm{PCP}=$ peptidyl carrier protein, $\mathrm{PKS}=$ polyketide synthase, TE $=$ thioesterase. $\mathrm{Question}$ mark in NRPS-2 domain indicates that this A domain is incomplete. 
Sequence analysis of albI, albIV, and albIX genes.

The proposed translational start site of albI (GTG) is preceded by a consensus ribosomal binding site (GAGGG) and begins at nucleotide 30,166 . The albI gene is $20,640 \mathrm{bp}$ in length, ending at nucleotide 50,805. The proposed translational start site of albIV (GTG) is preceded by a consensus ribosomal binding site (GAGG) and begins at nucleotide 52,382 . The albIV gene is $2,826 \mathrm{bp}$ in length, ending at nucleotide 55,207. The proposed translational start site of albIX
(ATG) is preceded by the less conserved ribosomal binding site (GTGG) and begins at nucleotide 24,882 . The albIX gene is 5,880 bp in length, ending at nucleotide 19,003. Using the terminator program (Brendel and Trifonov 1984), a putative rho-independent terminator was identified downstream from albIV (data not shown). No putative rho-independent terminators were found downstream from albI and albIX. The $236 \mathrm{bp}$ upstream from albI are $100 \%$ identical to the sequence upstream from $x a b B$ of $X$. albilineans strain Xa13 that was de-

Table 3. Comparison of conserved sequences in adenylation (A) condensation (C) peptidyl carrier protein (PCP), and thioesterase (TE) domains of peptide synthases and in putative A, C, PCP and TE domains of the Alb modules ${ }^{\mathrm{a}}$

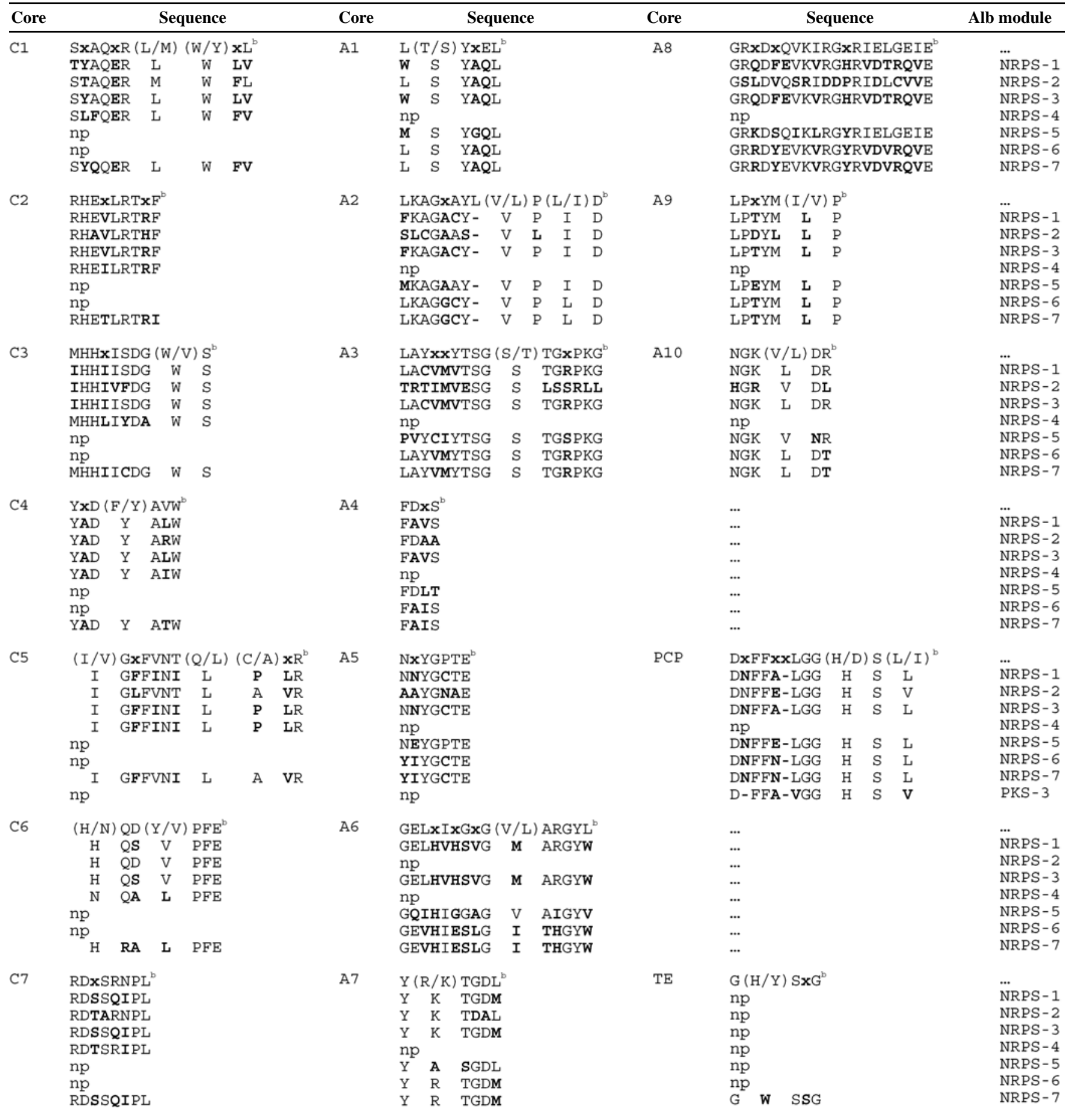

${ }^{a}$ As determined by Marahiel and associates (1997); $\mathrm{np}=$ not present.

${ }^{\mathrm{b}}$ Conserved sequences in A, C, PCP and TE domains in peptide synthases as determined by Marahiel and associates (1997); nonconserved amino acids are indicated in bold. 
scribed as containing a functional promoter during the phase of albicidin accumulation in $X$. albilineans (Huang et al. 2001). There are no close matches to the E. coli $\sigma 70$ promoter consensus sequence in the $706 \mathrm{bp}$ preceding the GTG start codon of albIV and in the $545 \mathrm{bp}$ preceding the ATG start codon of albIX.

Analysis of the albicidin synthases AlbI, AlbIV, and AlbIX.

Gene albI potentially encodes a protein of 6,879 amino acids (aa), designated AlbI, that is very similar to the potential product of the $x a b B$ gene from $X$. albilineans strain Xa13 from Queensland (Huang et al. 2001). Comparison of AlbI with XabB revealed that i) XabB is smaller $(4,801 \mathrm{aa})$, ii) the N-terminal regions from Met- 1 to Ile- 4325 of both proteins are identical except for five amino acids, and iii) the AlbI C-terminal region from Arg-6404 to the stop codon is $100 \%$ identical to the XabB C-terminal region from Arg-4326 to the stop codon.

The N-terminal region (from Met-1 to Asp-3,235) of AlbI is $100 \%$ identical to the corresponding region in $\mathrm{XabB}$, which previously was described as similar to many microbial modular PKS (Huang et al. 2001). This PKS region may be divided into three modules (Fig. 2). The module designated PKS-1 contains acyl-CoA ligase (AL) and acyl carrier protein (ACP1) domains. The module designated PKS-2 contains $\beta$-ketoacyl synthase (KS1) and $\beta$-ketoacyl reductase (KR) domains followed by two consecutive ACP domains (ACP2 and ACP3). The module designated PKS-3 contains a KS domain (KS2) followed by a PCP domain (PCP1). The motifs characteristic of these domains are $100 \%$ identical to those of $\mathrm{XabB}$, which previously were aligned with those from other organisms (Huang et al. 2001).
The PKS part of AlbI is linked by the PCP1 domain to four nonribosomal peptide synthase modules designated NRPS-1, NRPS-2, NRPS-3, and NRPS-4 (Fig. 2). NRPS-1, NRPS-2, and NRPS-3 modules display the ordered C, A, and PCP domains typical of such enzymes (Marahiel et al. 1997), and NRPS- 4 consists of a single $\mathrm{C}$ domain which may correspond to an incomplete NRPS module. Sequences characteristic of $\mathrm{C}, \mathrm{A}$, and PCP domains are conserved in these four NRPS, except in the A domain of the NRPS-2 module, suggesting that this latter A domain may be nonfunctional (Table 3). Comparison with XabB revealed that the NRPS-2 and NRPS-3 modules were not present in XabB, which contains only NRPS-1 and NRPS-4 modules (Fig. 2).

The potential product of albIV, designated AlbIV, is similar to the BA3 peptide synthase involved in bacitracin biosynthesis in Bacillus licheniformis (Table 2). AlbIV forms one NRPS module, designated NRPS-5, that contains only an A domain and a PCP domain (Fig. 2). Sequences characteristic of A and PCP domains are conserved in AlbIV (Table 3). The A domain present in AlbIV differs, however, from A domains commonly found in peptide synthases: conserved sequences corresponding to cores A8 and A9 in AlbIV are separated by a very long peptide sequence of 390 aa. This additional peptide sequence exhibits a significant similarity to the predicted $\mathrm{N}, \mathrm{O}$-acyltransferase $\mathrm{FeeH}$ (397 aa) involved in the substitution of an oxygen for an amide $\mathrm{NH}$, leading to the conversion of a peptide bond (R-CO-NH-R') to an ester bond (R-CO-O- $\mathrm{R}^{\prime}$ ) during the biosynthesis of a long-chain $\mathrm{N}$-acetyltyrosine from an environmental DNA gene cluster (Brady et al. 2002) (Table 2).

The potential product of albIX, designated AlbIX, is composed of two NRPS modules, designated NRPS-6 and NRPS-

Table 4. Comparison of signature sequences of Alb nonribosomal peptide synthase (NRPS) modules

\begin{tabular}{|c|c|c|c|c|c|c|c|c|c|c|}
\hline \multirow[b]{2}{*}{ Signature or code } & \multicolumn{10}{|c|}{ GsrA (Phe) numbering } \\
\hline & 235 & 236 & 239 & 278 & 299 & 301 & 322 & 330 & 331 & 517 \\
\hline Alb NRPS-5 ${ }^{\mathrm{a}}$ & D & $\mathbf{L}$ & $\mathbf{T}$ & $\mathbf{K}$ & I & G & $\mathbf{E}$ & $\mathbf{V}$ & $\mathbf{G}$ & $\mathbf{K}$ \\
\hline BacC-M5 (Asn) & $\mathrm{D}$ & $\mathrm{L}$ & $\mathrm{T}$ & $\mathrm{K}$ & I & $\mathrm{G}$ & $\mathrm{E}$ & $\mathrm{V}$ & $\mathrm{G}$ & $\mathrm{K}$ \\
\hline TyrC-M1 (Asn) & $\mathrm{D}$ & $\mathrm{L}$ & $\mathrm{T}$ & $\mathrm{K}$ & I & G & $\mathrm{E}$ & $\mathrm{V}$ & $\mathrm{G}$ & $\mathrm{K}$ \\
\hline Asn code & $\mathrm{D}$ & $\mathrm{L}$ & $\mathrm{T}$ & $\mathrm{K}$ & $\mathrm{L}$ & G & $\mathrm{E}$ & $\mathrm{V}$ & G & $\mathrm{K}$ \\
\hline Alb NRPS-1 ${ }^{b}$ & $\mathbf{A}$ & $\mathbf{V}$ & $\mathbf{K}$ & $\mathbf{Y}$ & $\mathbf{V}$ & $\mathbf{A}$ & $\mathbf{N}$ & D & $\mathbf{A}$ & $\mathbf{K}$ \\
\hline Alb NRPS-3 & $\mathbf{A}$ & $\mathbf{V}$ & $\mathbf{K}$ & $\mathbf{Y}$ & $\mathbf{V}$ & $\mathbf{A}$ & $\mathbf{N}$ & D & $\mathbf{A}$ & $\mathbf{K}$ \\
\hline Alb NRPS-6 & $\mathbf{A}$ & $\mathbf{I}$ & $\mathbf{K}$ & $\mathbf{Y}$ & $\mathbf{F}$ & $\mathbf{S}$ & $\mathbf{I}$ & D & $\mathbf{M}$ & $\mathbf{K}$ \\
\hline Alb NRPS-7 & $\mathbf{A}$ & $\mathbf{I}$ & $\mathbf{K}$ & $\mathbf{Y}$ & $\mathbf{F}$ & $\mathbf{S}$ & $\mathbf{I}$ & D & $\mathbf{M}$ & $\mathbf{K}$ \\
\hline TyrB-M1 (Pro) & $\mathrm{D}$ & $\mathrm{V}$ & Q & $\mathrm{S}$ & I & A & $\mathrm{N}$ & $\mathrm{V}$ & $\mathrm{V}$ & $\mathrm{K}$ \\
\hline VirS (Pro) & $\mathrm{D}$ & V & $\mathrm{Q}$ & $\mathrm{Y}$ & A & A & $\mathrm{H}$ & V & M & $\mathrm{K}$ \\
\hline EntF-M1 (Ser) & $\mathrm{D}$ & V & $\mathrm{W}$ & $\mathrm{H}$ & $\mathrm{F}$ & $\mathrm{S}$ & $\mathrm{L}$ & $\mathrm{V}$ & $\mathrm{D}$ & $\mathrm{K}$ \\
\hline$\beta$-Ala code & V & $\mathrm{D}$ & $\mathrm{W}$ & $\mathrm{V}$ & I & $\mathrm{S}$ & $\mathrm{L}$ & A & $\mathrm{D}$ & $\mathrm{K}$ \\
\hline Alb NRPS-1 ${ }^{c}$ & $\mathbf{A}$ & $\mathbf{F}$ & $\mathbf{V}$ & $\mathbf{Y}$ & $\mathbf{V}$ & $\mathbf{A}$ & $\mathbf{N}$ & D & $\mathbf{A}$ & $\mathbf{K}$ \\
\hline Alb NRPS-3 & $\mathbf{A}$ & $\mathbf{F}$ & $\mathbf{V}$ & $\mathbf{Y}$ & $\mathbf{V}$ & $\mathbf{A}$ & $\mathbf{N}$ & D & $\mathbf{A}$ & $\mathbf{K}$ \\
\hline Alb NRPS-6 & $\mathbf{A}$ & $\mathbf{F}$ & $\mathbf{V}$ & $\mathbf{Y}$ & $\mathbf{F}$ & $\mathbf{S}$ & I & D & $\mathbf{M}$ & $\mathbf{K}$ \\
\hline Alb NRPS-7 & $\mathbf{A}$ & $\mathbf{F}$ & $\mathbf{V}$ & $\mathbf{Y}$ & $\mathbf{F}$ & $\mathbf{S}$ & $\mathbf{I}$ & D & $\mathbf{M}$ & $\mathbf{K}$ \\
\hline DhbE (DHB) & $\mathrm{N}$ & $\mathrm{Y}$ & $\mathrm{S}$ & A & Q & $\mathrm{G}$ & V & $\mathrm{V}$ & $\mathrm{N}$ & $\mathrm{K}$ \\
\hline EntE (DHB) & $\mathrm{N}$ & $\mathrm{Y}$ & $\mathrm{S}$ & A & Q & $\mathrm{G}$ & $\mathrm{V}$ & $\mathrm{V}$ & $\mathrm{N}$ & $\mathrm{K}$ \\
\hline YbtE (Salycilate) & $\mathrm{N}$ & $\mathrm{F}$ & $\mathrm{C}$ & A & Q & G & $\mathrm{V}$ & $\mathrm{L}$ & $\mathrm{C}$ & $\mathrm{K}$ \\
\hline PchD (Salycilate) & $\mathrm{N}$ & $\mathrm{F}$ & $\mathrm{C}$ & A & Q & G & V & $\mathrm{L}$ & $\mathrm{C}$ & $\mathrm{K}$ \\
\hline $\operatorname{RifA}(\mathrm{AHB})^{\mathrm{d}}$ & $\mathrm{L}$ & $\mathrm{F}$ & $\mathrm{S}$ & A & $\mathrm{L}$ & $\mathrm{G}$ & A & G & A & $\mathrm{K}$ \\
\hline
\end{tabular}

a Alb NRPS-5 signature sequence determined according to the model proposed by Stachelhaus and associates (1999) compared with those of BacC-M5 (Asn) (Bacitracin synthetase 3, accession no. AAC06348) and TyrC-M1 (Asn) (Tyrocidine synthetase 3, accession no. AAC45930) and with the Asn code (Asn selectivity-conferring code defined by Stachelhaus and associates [1999]). Alb NRPS signature sequences are indicated in bold.

b Alb NRPS-1, -3, -6 and -7 signature sequences determined according to the model proposed by Stachelhaus and associates (1999) compared with those of Tyr-M1 (Pro) (Tyrocidine synthetase 2 module 1, accession no. AAC45929), VirS (Pro) (Virginiamycin S synthetase, accession no. CAA72310) and EntF-M1 (Ser) (Enterobactin synthase, accession no. AAA92015), and with the $\beta$-Ala code ( $\beta$-Ala selectivity-conferring code defined by Du and associates [2000]).

c Alb NRPS-1, -3, -6 and -7 signature sequences determined according to the model proposed by May and associates (2002) compared with those of DhbE (DHB) (Bacillibactin synthetase 1, accession no. AAN15214), EntE (DHB) (Enterobactin synthetase, accession no. CAB15188), YbtE (Salycilate) (Yersiniabactin synthase, accession no. NP-669710), PchD (Salycilate) (Pyochelin synthetase, accession no. AAD55799) and RifA NRPS (AHB) (Rifamycin synthase RifA, accession no. AAC01710).

${ }^{\mathrm{d}} \mathrm{AHB}=3$-amino-5-hydroxybenzoate and DHB = 2,3-dihydroxybenzoate. 
7. Sequences characteristic of domains A, C, and PCP are conserved in AlbIX (Table 3). NRPS-6 contains only one A and one PCP domain. NRPS-7 contains the three domains characteristic of NRPS modules (A-C-PCP) followed by a TE domain (Fig. 2; Table 3). This TE domain contains the "nucleophile elbow" GWSSG which is very similar to the consensus sequence described by Guenzi and associates (1998) for syringomycin synthetase (GGWSAGG).

\section{Analysis of the substrate specificity regions of AlbI, AlbIV, and AlbIX.}

Preliminary specificity assignments of albicidin synthases AlbI, AlbIV, and AlbIX NRPS modules were made by comparison of complete sequences between conserved motifs A4 and A5 with sequences in the GenBank database. The corresponding sequence of the AlbIV NRPS-5 module is most related to domain 5 of bacitracin synthase 3 (BA3) from $B$. licheniformis that was suggested to activate Asn (Konz et al. 1997). Corresponding sequences of AlbI and AlbIX NRPS-1, NRPS-3, NRPS-6, and NRPS-7 modules, apart from their very high similarity with $\mathrm{XabB}$, exhibited the highest degree of overall identity (39\%) with the Blm NRPS-2 module of the biosynthetic gene cluster for bleomycin from Streptomyces verticillus that specifies for $\beta$-Ala (Du et al. 2000). The sequence between motifs A4 and A5 of the AlbI NRPS- 2 could not be aligned significantly with any sequence present in the GenBank database. Comparison of this sequence with the corresponding sequence of GrsA (Phe) revealed that parts of the putative core and structural "anchor" sequences of AlbI NRPS-2 are deleted, suggesting that the AlbI NRPS-2 substrate binding pocket is not functional.

Using predictive models for NRPS substrate specificity, the AlbIV NRPS-5 signature is 100\% identical to the BacC-M5 (Asn) and the TyrC-M1 (Asn) signatures (Table 4). The AlbIV NRPS-5 signature also is identical to the Asn code, except that $\mathrm{L}$ is replaced by I at position 299 (Table 4). On the other hand, the AlbI and AlbIX NRPS-1, -3, -6, and -7 signatures did not match any of the defined codes, indicating that the substrates bound by these pockets are not yet known. The AlbI and AlbIX NRPS-1, -3, -6, and -7 signatures diverged from all NRPS signatures previously described, except from the XabB signature that is identical to the AlbI NRPS- 1 and -3 signatures. The signature most closely related to AlbI NRPS -1 and -3 specify Pro and the signature most closely related to AlbIX NRPS-6 and 7 specify Ser, but the degree of similarity in both cases is very weak (Table 4).

\section{Comparison of XALB1 with the $x a b B$ EcoRI fragment.}

The 16,511-bp DNA sequence of the EcoRI fragment described by Huang and associates (2001) as including fulllength $x a b B$ from Queensland strain Xa13 is identical to the 22,745-bp DNA sequence of the EcoRI fragment including albI from Florida strain Xa23R1 (Fig. 1), except that i) 5 nucleotides (nt) are different at positions 42,963, 42,972, $42,980,43,014$, and 43,071 of the XALB1 sequence, and ii) $6,234 \mathrm{nt}$, from positions 43,137 to 49,370 , are missing from the $x a b B$ gene sequence. The missing DNA sequence corresponds to one copy of the 2,727-bp DS2 duplicated sequence plus the region between the two copies of the DS2 duplicated sequence (Figs. 1 and 2).

In order to compare the activity of $x a b B$ and $a l b I$, pALB571, pALB646, and pEco646 were transferred by conjugation into $x a b B$ mutant LS157R1 (LS155-xabB::Tn5). Transfer into this mutant of the 16.5-kb EcoRI fragment cloned from $X$. albilineans strain Xa13 and containing $x a b B$ previously was shown to restore albicidin production (Huang et al. 2001). In the present study, we demonstrated that the transfer of pALB571,
pALB646, and pEco646 into $x a b B$ mutant LS157R1 (LS155$x a b B:: \operatorname{Tn} 5)$ also restored albicidin production.

\section{Confirmation of the XALB1 DNA sequence by Southern blot analyses.}

Southern blot hybridizations were performed to compare the actual restriction patterns of XALB1 with the theoretical restriction profiles determined from the 55,839-bp XALB1 DNA sequence (GenBank accession number AJ586576). Total genomic DNA from Xa23R1 and plasmid DNA of the pALB571 cosmid were digested by EcoRI, NcoI, PstI, SacI, and KpnI and hybridized with three different probes: i) a small probe of $403 \mathrm{bp}$ which corresponds to the part of the large 2,737-bp DS2 internal duplication that does not encode conserved sequences from the $\mathrm{C}, \mathrm{A}$, or PCP domains; ii) the $\mathrm{pBC} / \mathrm{C}$ plasmid; and iii) pALB571. The 403-bp probe corresponded to a polymerase chain reaction (PCR) fragment amplified from cosmid pALB571 using primers AlbIrepeatF (5'cgacaccagaact tcccg $\left.3^{\prime}\right)$ and AlbIrepeatR (5'actgcccatcgctcacgc $\left.3^{\prime}\right)$. The DNA sequence of this small probe did not match any other sequence of the databases except $x a b B$. The 403-bp probe revealed the presence of the same DNA fragments in Xa23R1 and pALB571 corresponding in size to the theoretical restriction profiles: i) a unique DNA fragment containing the two copies of the large internal duplication DS2 for EcoRI and SacI; and ii) two separate DNA fragments, each containing one of the two copies of the large internal duplication DS2 for NcoI, PstI, and KpnI. The pALB571 and pBC/C probes revealed in $\mathrm{Xa23R} 1$ and pALB571 the presence of DNA fragments corresponding in size to the theoretical profiles determined from the 55,839-bp XALB1 DNA sequence and from the pUFR043 map (De Feyter and Gabriel 1991).

Southern blot hybridization also was performed to look for the presence of the large internal duplication DS2 in seven strains (not including Xa13 but including the $X$. albilineans mutant LS156R1, LS155-xabA::Tn5) (Huang et al. 2000b) iso-

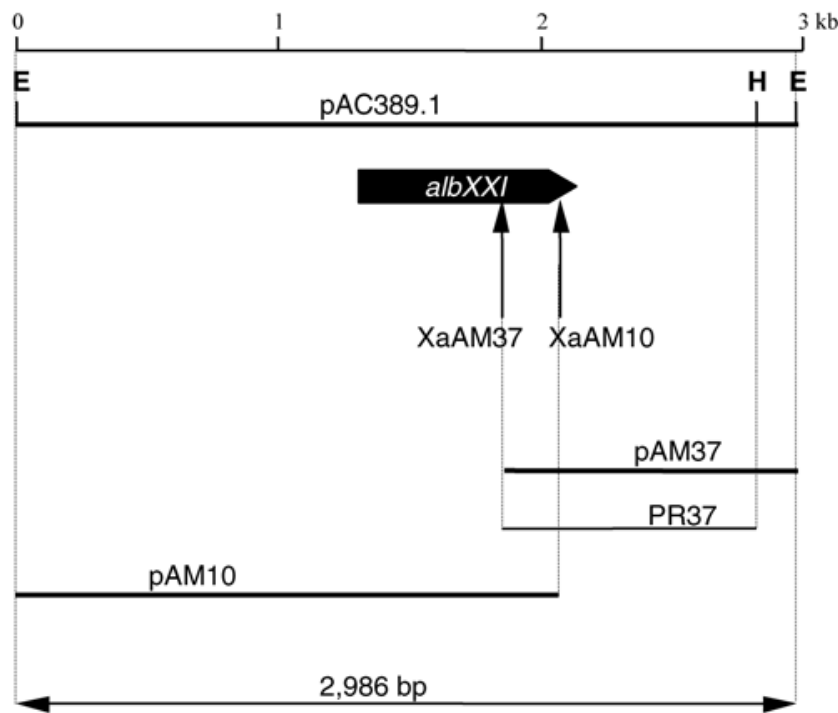

Fig. 3. Physical map and genetic organization of the DNA region containing gene cluster XALB2 involved in albicidin production. Restriction maps: E and $\mathrm{H}$ are restriction sites for EcoRI and HindIII, respectively. The DNA insert carried by plasmid pAC389.1 is represented by the bar at the top of the figure. Position of Tn5 insertional sites of mutants XaAM37 and XaAM10 determined by sequencing are indicated by vertical arrows. DNA region corresponding to Tn5 flanking sequence in pAM37 and pAM10 plasmids and in PR37 DNA fragment are represented by bars at the bottom of the figure. Genetic organization: The location and direction of $a l b X X I$ is indicated by a black and thick arrow. 
lated from five different countries (Australia, Reunion Island, Kenya, Zimbabwe, and the United States). Total genomic DNA of these seven strains was digested by KpnI and EcoRI, and hybridized with the 403-bp probe and with the $\mathrm{pBC} / \mathrm{C}$ plasmid. Both probes revealed the presence of the two KpnI DNA fragments corresponding in size to XALB1 fragments B and $\mathrm{C}$ and one unique EcoRI fragment corresponding in size to the XALB1 23-kb fragment (data not shown). These results indicated that all strains in the present study contain $a l b I$ and not $x a b B$ because, in albI, both the 403-bp and the pBC/C plasmid probes hybridized with the large internal duplication DS2 present in both DNA fragments B and C (Fig. 1).

\section{Cloning and sequencing of the XALB2 gene cluster.}

The flanking sequence of the Tn5 insertional site from mutant XaAM37, which was not complemented by either pALB540 or pALB571 (Rott et al. 1996), was used to identify cosmid pALB389. A fragment of the insert of pALB389 was subcloned into plasmid pAC389.1 (Table 1) and both plasmids complemented mutant XaAM37, confirming that the second region involved in albicidin production, XALB2, was present in the insert of pAC389.1. Another albicidin-defective mutant, XaAM10, also was complemented by pALB389 and pAC389.1. The complete double-strand nucleotide sequence of the 2,986bp EcoRI-EcoRI insert of pAC389.1 was determined by sequencing plasmids pAC389.1, pAM10, and pAM37 (Fig. 3). The Tn5 insertional sites of XaAM10 and XaAM37 were located at position 2,107 and 1,882 , respectively.

\section{Homology analysis and genetic organization of XALB2.}

The sequence of 2,986 bp containing XALB2 is $99.4 \%$ identical to the sequence of 2,989 bp containing $x a b A$ described in $X$. albilineans strain LS155 from Queensland (Huang et al. 2000b). The Tn5 insertional site of mutant LS156 described in $x a b A$ (Huang et al. 2000b) is $15 \mathrm{bp}$ upstream from the insertional site of XaAM37. The ORF disrupted in XaAM37 and XaAM10, designated albXXI, is identical to $x a b A$ ( $837 \mathrm{bp}$ ), except that a $\mathrm{C}$ replaces a $\mathrm{T}$ at position 1,642 of XALB2. The potential product of albXXI is $100 \%$ identical to the potential product of $x a b A$, described as a phosphopantetheinyl transferase (Huang et al. 2000b). There are no close matches to the $E$. coli $\sigma 70$ promoter consensus sequence, and no putative RBS site upstream from the putative start codon ATG of albXXI. The putative factor-independent transcription site described at 42 bp downstream from the TGA stop codon of $x a b A$ (Huang et al. 2000b) also is present at the same position downstream from albXXI.

\section{DISCUSSION}

Several NRPS gene clusters have been described for toxin production by phytopathogenic pseudomonads (Guenzi et al. 1998; Scholz-Schroeder et al. 2001, 2003), but this study describes for the first time a complete mixed PKS-NRPS biosynthetic gene cluster for toxin production in the genus Xanthomonas. Comparison of $a l b I$ and $x a b B$ suggests that the XALB1 gene cluster from $X$. albilineans strain Xa23R1 from Florida differs significantly from the albicidin gene cluster from $X$. albilineans strain Xa13 from Queensland. The difference between the two clusters may be important because the deletion of 6,234 bp in $x a b B$ could mean that the two clusters do not encode the same toxin. Our results indicated that all strains in the present study contain $a l b I$ and not $x a b B$, and that $x a b B$ and $a l b I$ complemented the same albicidin-defective mutant LS157. Alternatively, it is possible that the reported DNA sequence of $x a b B$ is simply incomplete and missing 6,234 bp of DNA sequence encoding 2,078 aa.

Our mutagenesis and complementation results demonstrated that three PKS and NRPS genes (albI, albIV, and albIX) are involved in albicidin biosynthesis. XALB1 potentially also may encode i) one hydroxybenzoate-CoA ligase, AlbVII; ii) two methyltransferases, AlbII and AlbVI; iii) one esterase, AlbXI; iv) one para-amino benzoate synthase, AlbXVII; v) one hydroxybenzoate synthase, AlbXX; vi) one carbamoyl transferase, AlbXV; vii) one amino-deoxychorismate lyase, AlbXVIII; viii) two regulatory proteins, AlbIII and AlbVIII; ix) two resistance proteins, AlbXIV and AlbXIX; and x) three additional proteins, AlbX, AlbXII, and AlbXIII, similar to proteins with unknown functions. One resistance gene, albF (100\% identical to albXIV), and one modifying gene, $x a b C$ ( $100 \%$ identical to $a l b I I)$, previously were described as respectively involved in albicidin resistance (accession number

A

$\begin{array}{ll}\text { RifA-1 } & \text { LGRVDVLQPACFAVMVGLAAVWESVGVRPDAVVGHSQGEI } \\ \text { RifA-2 } & \text { LDQTMYTQGALFAVETALFRLFESWGVRPGLLAGHSIGEL } \\ \text { RifA-3 } & \text { LDRVDVVQPASFAMMVGLAAVWTSLGVTPDAVLGHSQGEI } \\ \text { RifB-1 } & \text { LDRVDVVQPASFAVMVGLAAVWESVGVRPDAVVGHSQGEI } \\ \text { RifE-1 } & \text { LNQTVFTGAGLFAVESALFRLAESWGVRPDVVLGHSIGEI } \\ \text { BlmVIII } & \text { ADDTRAAQPALFAVEYALARTLMDWGVRPAAMLGHSLGEV }\end{array}$

B

$\begin{array}{ll}\text { AlbXIII } & \text { LEDRPRHIRAVIDTLTGHAQFGPAIQAHNVAVIGHSVGGY } \\ \text { FenF } & \text { TRTMNAQPAILTVSVIAYQVYMQEIGIKPHFLAGHSLGEY } \\ \text { PedC } & \text { DRLIHTHPALFMVQYALAKSLLARGLPAPDFLIGASLGEF } \\ \text { PedD } & \text { RLTQYTQVALYVVNALTYRQHLQQGGGLPDFVAGHSLGEY } \\ \text { LnmG } & \text { ALVFPGQGSQRKGMGADLFARFPDLTRQADTVLGHSVEEL }\end{array}$

Fig. 4. A, Alignment of the conserved motifs in acyltransferase (AT) domains from several polyketide synthase modules, RifA-1, -2, and -3, RifB-1, RifE-1 (Rifamycin synthase) (August et al. 1998), and BlmVIII (Bleomycin synthase) (Du et al. 2000). Identical amino acids are shown in bold. B, Alignment of several trans-acting AT domains from AlbXIII (this study), FenF (mycosubtilin synthase) (Duitman et al. 1999), PedC and PedA (pederin synthase) (Piel 2002), and LnmG (leinamycin synthase) (Cheng et al. 2003). Amino acids identical to conserved AT domains motifs are shown in bold. 
AAL01877) and in albicidin biosynthesis (Huang et al. 2000a). Additionally, albV is $100 \%$ identical to the thp gene described by Huang and associates (2000a). Insertional mutagenesis of the thp gene blocked albicidin production but transcomplementation of the thp mutant with the thp gene failed (Huang et al. 2000a), indicating the involvement in albicidin production of a downstream gene in a putative thp operon. This operon may contain albVI, albVII, or albVIII but not albIX because albIX mutants were complemented by pEco4. Further mutagenesis studies will be necessary to confirm the involvement of the other XALB1 ORFs in albicidin biosynthesis.

Most of the bacterial NRPS gene clusters described up to now are organized along the chromosome in a linear order that parallels the order of amino acids in the resultant peptide, following the "colinearity rule" for the NRPS-template assembly of peptides from amino acids (Cane 1997; Cane and Walsh
1999; Cane et al. 1998; von Döhren et al. 1999). The three PKS and seven NRPS modules encoded by XALB1 apparently are not organized according to this "colinearity rule" because of the following features: i) NRPS and PKS genes are expressed in two divergent orientations; ii) no AT domain was identified in PKS-2 and PKS-3 domains, suggesting involvement of a separate enzyme; and iii) the A domain of NRPS-2 is not functional, suggesting the involvement of a trans-acting A domain. An exception to the colinearity rule already has been reported for the syringomycin synthetase of $P$. syringae (Guenzi et al. 1998), for the exochelin synthetase of Mycobacterium smegmatis (Yu et al. 1998), and for the bleomycin synthetases of S. verticillus (Du et al. 2000).

The PKS-1 module that contains an AL domain and an ACP domain (ACP1) may be responsible for the initiation of the albicidin backbone assembly by loading a starter unit. The PKS-1 module is followed by the PKS-2 module, which con-

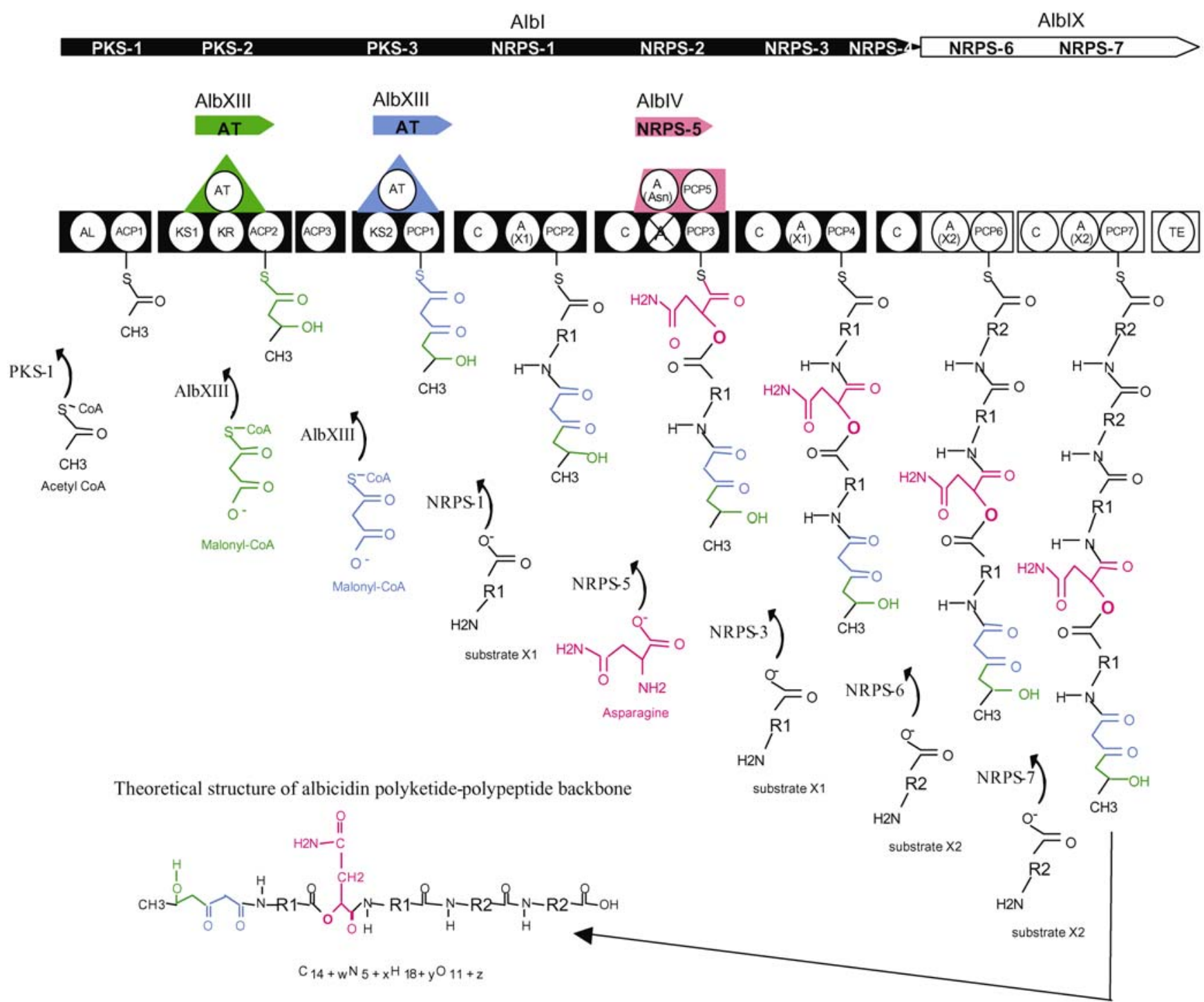

Fig. 5. Linear model for the albicidin megasynthetase-template assembly of the polyketide-polypeptide backbone. Genes are defined by thick arrows. Each polyketide synthase (PKS) and nonribosomal peptide synthase (NRPS) subunit is depicted by an open box, in which the type and the order of the individual domains are indicated from the left (N-terminal) to the right (C-terminal). Subunits from trans-acting domains are indicated in colored boxes. NRPS and PKS domains are abbreviated as follows: $\mathrm{A}=$ adenylation, $\mathrm{ACP}=$ acyl carrier protein, $\mathrm{AL}=$ acyl-CoA ligase, $\mathrm{AT}=$ acyltransferase, $\mathrm{C}=$ condensation, $\mathrm{KR}=$ ketoreductase, $\mathrm{KS}=$ ketoacyl synthase, $\mathrm{PCP}=$ peptidyl carrier protein. Asn designates asparagine. $\mathrm{X} 1$ and $\mathrm{X} 2$ indicate unidentified substrates incorporated by NRPS-1 and -3 and NRPS-6 and -7, respectively. The crossed A domain in NRPS-2 indicates that this deleted domain may be not functional. The intermediates of polyketide-polypeptide assembly are shown attached to the ACP or PCP domains at the point before intramolecular transfer to a succeeding $\mathrm{KS}$ or $\mathrm{C}$ domain. Green and blue colors show which portions of the albicidin backbone are provided by the two malonyl-CoA catalyzed by the trans-acting AT domain of AlbXIII. Pink color shows which portions of the albicidin backbone are provided by asparagine catalyzed by the trans-acting A domain of NRPS-5 (AlbIV). The O atom transferred by NRPS-5 at the level of the peptide bond between asparagine and substrate X1 is shown in bold. 
tains a $\mathrm{KS}$ domain and a $\mathrm{KR}$ domain upstream from two ACP domains (ACP2 and ACP3), and it lacks any discernable AT domain. Tandem ACP domains are unusual within PKS modules but have been shown to occur in the biosynthesis of several fungal and bacterial polyketide synthases (Albertini et al. 1995; Mayorga and Timberlake 1992; Takano et al. 1995; Yu and Leonard 1995). However, the significance of the tandem ACP domains in these systems is unknown. The absence of an AT domain in the PKS-2 module suggests that a separate AT domain is indispensable for the elongation of the acyl-chain initiated by this module. Separate AT enzymes encoded elsewhere in the genome were described for PKS modules lacking AT domains in other systems (Albertini et al. 1995; Cheng et al. 2003; Duitman et al. 1999; Paitan et al. 1999; Zhu et al. 2002). The conserved motif GHSxG described in the discrete acyltransferases involved in these systems is present in AlbXIII, suggesting that this protein could complement the missing AT domain in PKS-2 (Fig. 4). The PKS-3 module is located upstream from the NRPS modules and, therefore, should be involved in the linkage of polyketide and polypeptide moieties. The presence of a KS domain in the PKS-3 module suggests the involvement of a trans-acting AT domain rather than an A domain. By analogy with the BlmVIII PKS module, which is involved in the linkage of polypeptide and polyketide moieties of bleomycin and which contains an AT domain followed by a PCP domain (Du et al. 2000), the presence of a PCP is not incompatible with the interaction of AlbI PKS-3 module with the putative trans-acting acyltransferase AlbXIII.

The NRPS-1, -2, and -3 modules display the ordered C, A, and PCP domains, suggesting that they are involved in the incorporation of three amino acid residues. The A domain of the NRPS-2 module exhibits poor consensus at A2, A3, A5, A7, A8, A9, and A10 motifs and lacks completely the A6 motif (Table 3). In addition, the NRPS-2 substrate binding pocket is partially deleted. These features strongly suggest that the NRPS-2 A domain is inactive and that the loading of an amino acid on the NRPS-2 PCP domain (PCP3) possibly is catalyzed by a trans-acting A domain. Similar trans-complementation of an incomplete and deleted A domain was described for bleomycin biosynthesis (Du et al. 2000). A putative candidate for this trans-acting A domain is the NRPS-5 A domain present in AlbIV because of the lack of a C domain in NRPS-5 (Fig. 2). As a consequence of the interaction between NRPS-2 and NRPS-5, two PCP domains (PCP-3 and PCP-5) must be involved in the binding of the amino acid activated by the NRPS-5 A domain. The presence of two PCP domains also was described for syringomycin biosynthesis during the interaction between SyrB, which contains A and PCP domains, and the last module of SyrE, which contains C and PCP domains (Guenzi et al. 1998). The existence of two PCP domains does not necessarily indicate a competition between them, because they could have different functions in the transfer of intermediates. The NRPS-4 module contains only a C domain, which may transfer the intermediate product synthesized by AlbI and AlbIV to the PCP-6 domain present in the AlbIX NRPS- 6 module. The N-terminal A domain of the NRPS-6 module then may be involved in the incorporation of one amino acid residue. Similar transfers were described for mycosubtilin biosynthesis, in which the $\mathrm{MycA}$ and $\mathrm{MycB} \mathrm{C}$-terminal $\mathrm{C}$ domains interact with the $\mathrm{MycB}$ and $\mathrm{MycC} \mathrm{N}$-terminal $\mathrm{A}$ domains, respectively (Duitman et al. 1999). The NRPS-7 module which displays the ordered $\mathrm{C}, \mathrm{A}$, and PCP domains should be involved in the incorporation of the last amino acid residue. Indeed, this module also contains the single chainterminating TE domain known to be responsible for detachment of the mature polyketide-polypeptide backbone from the complex of enzymes.
On the basis of the deduced functions of individual NRPS and PKS domains, we have aligned the three PKS and the seven NRPS modules and propose a model for the albicidin backbone biosynthesis (Fig. 5). In this model, PKS-1 is responsible for initiation of albicidin assembly by loading acetyl-CoA onto ACP1. PKS-2 and the trans-acting AlbXIII are responsible for loading malonyl CoA on ACP2 or ACP3. The $\mathrm{KR}$ domain present in PKS-2 is responsible for reduction of the $\mathrm{CO}$ function at position ${ }^{2} \mathrm{C}$ of the albicidin backbone. PKS3 and the trans-acting AlbXIII are responsible for loading malonyl CoA on PCP1. NRPS-1 and NRPS-3 are responsible for loading the same unknown substrate X1 on PCP2 and PCP4, respectively. NRPS-2 and the trans-acting NRPS-5 are responsible for loading asparagine on PCP3 or PCP5. The additional peptide, similar to the predicted $N, O$-acyltransferase FeeH present in the NRPS-5 A domain, could be responsible for conversion of the peptide bound between substrate $\mathrm{X} 1$ and asparagine to an ester bond as proposed for the $\mathrm{FeeH}$ protein (Brady et al. 2002). NRPS-6 and NRPS-7 are responsible for loading the same unknown substrate X2 on PCP6 and PCP7, respectively. The domain NRPS-7 TE is responsible for the detachment of the albicidin backbone.

The substrates of PKS-1, PKS-2, and PKS-3 proposed in our model correspond to the most common substrates of PKS enzymes (Du and Shen 2001). The substrates of NRPS-1 and -3 and NRPS- 6 and -7 , designated X1 and X2, respectively, in our model, remain unknown. Binding-pocket residues forming the NRPS codes have been classified according to their variability (Table 4) (Stachelhaus et al. 1999). According to this classification, residues Asp235 and Lys517, which mediate key interactions with the $\alpha$-amino and $\alpha$-carboxylate groups, respectively, of the substrate, are invariant. The AlbI and AlbIX NRPS-1, -3, -6, and -7 signatures are not totally in accord with this classification. Invariant residue Lys517 is conserved in the four NRPS signatures, indicating the presence of a carboxylate group in the corresponding substrates, but the Asp235Ala alteration is not consistent with an $\alpha$-amino acid substrate. The Asp235Val alteration observed in the $\beta$-Ala specificity-conferring code (Table 4) suggests that substrates $\mathrm{X} 1$ and $\mathrm{X} 2$ are not $\alpha$-amino acids but do contain an amino group and a carboxylate group. Identification of several aromatic rings in albicidin (Birch and Patil 1985a,b) suggests that $\mathrm{X} 1$ and $\mathrm{X} 2$ are aromatic substrates. A similar aromatic amino carboxy acid substrate, the 3-amino-5-hydroxybenzoate (AHB), is recognized specifically and activated by the RifA NRPS during rifamycin synthesis (Admiraal et al. 2001). The RifA NRPS is similar to other aryl acid-activating domains like DhbE, which specifies the 2,3-dihydroxybenzoate (DHB), and YbtE and PchD, which specify salicylate and for which aryl acid specificity codes were defined (May et al. 2002). These aryl acid-activating domains always are involved in the loading of a starter unit in which only the carboxylate group is involved in bond formation. The corresponding codes of AlbI NRPS -1 and 3 exhibit some similarity with the RifA (AHB) code (Table 4), supporting the idea that these two Alb NRPS modules specify an aromatic amino carboxy acid substrate. Nevertheless, AlbI and AlbIX NRPS-1, -3, -6, and -7 primary sequences between motifs A4 and A5 are more closely related to GrrA (Phe) and Blm NRPS-2 ( $\beta$-Ala) than to RifA (AHB) and DhbE (DHB), supporting the idea that Alb NRPS modules, unlike aryl acid-activating domains, are involved in the loading of an extender unit in which both carboxylate and amino groups participate in the formation of peptide bonds.

The theoretical structure of the albicidin backbone synthesized according to our model (Fig. 5) is compatible with the chemical characteristics of albicidin from Hawaii strain LS2 described by Birch and Patil (1985a,b). The incorporation of 
aromatic substrates by NRPS-1, $-3,-6$, and -7 means that the $\mathrm{R} 1$ and $\mathrm{R} 2$ groups from substrates $\mathrm{X} 1$ and $\mathrm{X} 2$, respectively, contain at least six carbon atoms, corresponding to one aromatic ring. The total number of carbon atoms in the theoretical structure of albicidin backbone then would be 38, which corresponds to the 14 carbon atoms indicated in Figure 5 plus the 24 carbon atoms $(4 \times 6)$ of R1 and R2. An additional carbon atom putatively would be added by the $O$-methyltransferases AlbII and AlbVI, leading to a total number of 40 carbon atoms in the final theoretical albicidin structure. This number is in accordance with the number of carbon atoms determined from proton and ${ }^{13} \mathrm{C}$ NMR spectroscopy (approximately 38 carbon atoms) (Birch and Patil 1985a,b). In addition, because there are two R1 groups and two R2 groups in albicidin, two equivalent carbon atoms from, for example, the two R1 groups, may have been interpreted as one by Birch and Patil, and the same could be true for the two R2 groups. The presence of a $\mathrm{COOH}$ group in the theoretical structure of the albicidin backbone also is compatible with the previous analysis of albicidin. Incorporation of the nonproteogenic substrates $\mathrm{X} 1$ and $\mathrm{X} 2$ and conversion of the peptide bond between substrate $\mathrm{X} 1$ and asparagine to an ester bond would explain why albicidin is insensitive to pronase (Birch and Patil 1985a,b). The presence of one ester bond also is in accord with the fact that albicidin is detoxified by the AlbD esterase (Zhang and Birch 1997). In vitro characterization of the substrates specifically incorporated by the AT and A domains present in the albicidin biosynthetic enzymes may allow us to confirm our model and to propose theoretical chemical structures. Comparison of these theoretical structures with the proton and ${ }^{13} \mathrm{C}$ NMR spectroscopy analyses of albicidin and preparation of synthetic samples corresponding to the proposed structures may help to confirm the structure of albicidin.

\section{MATERIALS AND METHODS}

\section{Bacterial strains, plasmids, and culture conditions.}

The source of bacterial strains and their relevant characteristics are described in Table 1. X. albilineans strains were cultured routinely on modified Wilbrink's (MW) medium at $28^{\circ} \mathrm{C}$ without benomyl (Rott et al. 1994). For long-term storage, highly turbid distilled water suspensions of $X$. albilineans were frozen at $-80^{\circ} \mathrm{C}$. For $X$. albilineans, MW medium was supplemented with the following antibiotics as required at the concentrations indicated: kanamycin at 10 or $25 \mu \mathrm{g} / \mathrm{ml}$ and rifampicin at $50 \mu \mathrm{g} / \mathrm{ml}$. E. coli strains were grown on LuriaBertani (LB) agar or in LB broth at $37^{\circ} \mathrm{C}$ and were maintained and stored according to standard protocols (Sambrook et al. 1989). For E. coli, LB medium was supplemented with the following antibiotics as required at the concentrations indicated: kanamycin at $50 \mu \mathrm{g} / \mathrm{ml}$ and ampicillin at $50 \mu \mathrm{g} / \mathrm{ml}$.

\section{Bacterial conjugation.}

DNA transfer between $E$. coli donor (DH5 $\alpha /$ relevant plasmid) (Table 1) and rifampicin-resistant $X$. albilineans recipients (X. albilineans strains XaAM) (Table 1) was accomplished by triparental conjugation with plasmid pRK2073 as the helper as described previously (Rott et al. 1996).

\section{Albicidin production assay.}

Albicidin production was tested by a microbiological assay as described previously (Rott et al. 1996). Rifampicin- and kanamycin-resistant exconjugants were spotted with sterile toothpicks (2-mm-diameter spots) onto plates of SPA medium ( $2 \%$ sucrose, $0.5 \%$ peptone, and $1.5 \%$ agar) and incubated at $28^{\circ} \mathrm{C}$ for 2 to 5 days. The plates then were overlaid with a mixture of $E$. coli DH5 $\alpha$ ( $10^{7}$ cells in $2 \mathrm{ml}$ of distilled water) plus $2 \mathrm{ml}$ of molten $1.5 \%$ (wt/vol) Noble agar (Difco, Becton
Dickinson, Le Pont de Claix, France) at approximately $65^{\circ} \mathrm{C}$ and examined for growth inhibition zones after $24 \mathrm{~h}$ at $37^{\circ} \mathrm{C}$.

\section{Nucleic acid manipulations.}

Standard molecular techniques were used to manipulate DNA (Sambrook et al. 1989) except for total genomic DNA preparation of $X$. albilineans. Total genomic DNA of $X$. albilineans for Southern blot hybridization was prepared as described by Gabriel and De Feyter (1992).

\section{PCR conditions.}

PCR amplifications were performed in an automated thermal cycler PTC-100 (MJ Research, Inc, Watertown, MA, U.S.A.). The 25- $\mu$ l PCR reaction mix consisted of $100 \mathrm{ng}$ of genomic DNA or $1 \mathrm{ng}$ of plasmid DNA, $2.5 \mu \mathrm{l}$ of $10 \times$ PCR buffer without $\mathrm{MgCl}_{2}$ (Eurobio, Les Ulis, France), $80 \mu \mathrm{M}$ dNTP mix, 2.5 units of EUROBIOTAQII (Eurobio), 25 pmoles of each primer, $2.0 \mathrm{mM} \mathrm{MgCl}_{2}$ (Eurobio), and sterilized distilled water to final volume. The PCR program was $95^{\circ} \mathrm{C}$ for 2 min, 25 cycles at $94^{\circ} \mathrm{C}$ for $1 \mathrm{~min}, \mathrm{~T}_{\mathrm{m}}$ (melting temperature) for $1 \mathrm{~min}$, and $72^{\circ} \mathrm{C}$ for $1 \mathrm{~min}$, with a final $72^{\circ} \mathrm{C}$ extension for 5 min. $T_{m}$ temperature was determined for each pair of primers and varied between 55 and $60^{\circ} \mathrm{C}$. A 5- $\mu$ l aliquot of each amplified product was analyzed by electrophoresis through a $1 \%$ agarose gel. For sequencing, PCR products were cloned with the pGEM-T Easy Vector System (Promega Corp., Madison, WI, U.S.A.).

\section{Oligonucleotide synthesis and DNA sequencing.}

Oligonucleotides were purchased from Genome Express (Grenoble and Montreuil, France). Automated DNA sequencing was carried out on double-stranded DNA by the dideoxynucleotide chain termination (Sanger et al. 1977) using a Dye Terminator Cycle Sequencing kit and an ABI Perkin-Elmer sequencer according to the manufacturer's procedure. Both DNA strands were sequenced with universal primers or with internal primers (20 mers). This service was provided by Genome Express (Grenoble, France). Computer-aided sequence analyses were carried out using Sequence Navigator (Applied Biosystems, Inc., Norwalk, CT, U.S.A.) and SeqMan (DNASTAR Inc., Madison, WI, U.S.A.) programs.

\section{Sequence analysis.}

Nucleotide sequences were translated in all six reading frames using EditSeq (DNASTAR Inc.). Potential products of ORFs longer than 100 bases were compared with protein databases by the PSI-BLAST program (Swiss-Prot and GenBank) on the NCBI site using the Altschul program (Altschul et al. 1997).

\section{Sequencing of the 55,839-bp region \\ from $X$. albilineans containing XALB1.}

DNA fragments F, E, B, C, I, and G, generated by the digestion of cosmid pALB571 (Rott et al. 1996) with EcoRI, KpnI, or both, were subcloned into pBCKS $(+)$ and were sequenced from the resulting subclones, $\mathrm{pBC} / \mathrm{F}, \mathrm{pBC} / \mathrm{E}, \mathrm{pBC} / \mathrm{B}, \mathrm{pBC} / \mathrm{C}$, $\mathrm{pBC} / \mathrm{I}$, and $\mathrm{pBC} / \mathrm{G}$. DNA fragment $\mathrm{D}^{\prime}$, which corresponds to the part of fragment D present in cosmid pALB571, was sequenced from plasmid pUFR043/D', obtained following self ligation of the complete EcoRI-digested cosmid pALB571. DNA fragment $\mathrm{H}$ was sequenced from pAM45.1 (Rott et al. 1996), obtained following cloning into vector pBR325 of the 12-kb EcoRI fragment carrying Tn5 and flanking sequences from mutant strain XaAM45. DNA fragment $\mathrm{A}^{\prime}$ contains the part of fragment A present in cosmid pALB571 and was subcloned into vector $\mathrm{pBCKS}(+)$, and the resulting plasmid $\mathrm{pBC} / \mathrm{A}^{\prime}$ was used for sequencing. The presence of a large inter- 
nal duplication made alignment of sequence data obtained from pBC/A' difficult. This difficulty was resolved using sequence data obtained from an additional plasmid, pAM4, obtained following cloning into vector pBluescript II KS (+) of the $12-\mathrm{kb}$ EcoRI fragment carrying Tn5 and flanking sequences from mutant strain XaAM4, which contains only one copy of the large internal duplication. Sequence data from $\mathrm{pBC} / \mathrm{A}^{\prime}$ were used to determine the first $1,543 \mathrm{bp}$ of fragment $\mathrm{A}^{\prime}$ between nucleotides C-19,001 and G-20,543. Sequence data from pAM4 and pBC/A' were used to determine the last $4,825 \mathrm{bp}$ of fragment $A^{\prime}$ between nucleotides G-21,653 and G-26,477. The overlapping region between nucleotides G-20,469 and C22,159 was amplified by PCR from cosmid pALB571 using primers contig13-1160 (5'gcgtaccgttgtccagtagg3') and pAM414 (5'gctggaaaccgagaatctga $\left.3^{\prime}\right)$, and was sequenced. Resulting sequence data were used to complete sequencing of DNA fragment $\mathrm{A}^{\prime}$. The junctions $\mathrm{A} / \mathrm{F}, \mathrm{F} / \mathrm{H}, \mathrm{H} / \mathrm{E}, \mathrm{E} / \mathrm{B}, \mathrm{B} / \mathrm{C}, \mathrm{C} / \mathrm{I}, \mathrm{I} / \mathrm{G}$, and G/D between corresponding DNA fragments were sequenced directly from cosmid pALB571. An EcoRI DNA fragment containing fragments $\mathrm{A}$ and $\mathrm{F}$ was subcloned from pALB540 into pBCKS (+), and the resulting plasmid pBC/AF was used to determine the part of DNA fragment $A$ which was not present in cosmid pALB571 between nucleotides G-13,682 and G-19,001. EcoRI DNA fragments $\mathrm{J}, \mathrm{K}, \mathrm{L}$, and $\mathrm{N}$ were subcloned from pALB540 into pBCKS (+) and were sequenced from resulting plasmids $\mathrm{pBC} / \mathrm{J}, \mathrm{pBC} / \mathrm{K}, \mathrm{pBC} / \mathrm{L}$, and $\mathrm{pBC} / \mathrm{N}$. The junctions $\mathrm{L} / \mathrm{K}, \mathrm{K} / \mathrm{J}$, and $\mathrm{J} / \mathrm{A}$ between corresponding DNA fragments were sequenced directly from cosmid pALB540. The DNA region between nucleotides G-7,517 and T-8,721 was amplified by PCR from cosmid pALB540 using primers E114 (5'gacacgatcagccgctagga3') and EI4-380 (5'accagcagttgggccagcct $\left.3^{\prime}\right)$ and sequenced. The resulting sequence data were used to determine the sequence of fragment $M$ and of junctions N/M and $\mathrm{M} / \mathrm{L}$. The double-strand nucleotide sequence of 55,839 bp containing the entire gene cluster XALB1 has been deposited with GenBank (accession number AJ586576).

\section{Subcloning of albI, albIV, and albIX genes.}

pEco646 resulted from complete digestion of pALB646 by EcoRI and self ligation. pEco33lacZ and pEco4 resulted from a partial EcoRI digestion and self ligation of pALB571. The EcoRI-XbaI insert of pEco33lacZ containing DNA fragments $\mathrm{G}$ and $\mathrm{D}^{\prime}$ was subcloned into pBKS between EcoRI and XbaI sites. The KpnI-XbaI insert from the resulting plasmid was cloned between KpnI and SpeI sites of a modified pUFR043 plasmid in which a SpeI site was added at the level of the EcoRI site using an EcoRI/SpeI adaptor (5'aattgactagtc 3'), and the resulting plasmid was designated pEco33 rev. Plasmid pEco4SalI resulted from the complete SalI digestion and self ligation of $\mathrm{pEco} 4$.

\section{Cloning and sequencing of the XALB2 gene cluster.}

The 6-kb EcoRI fragment carrying Tn5 and flanking sequence from strain XaAM37 was cloned in pBR325 and the resulting plasmid was designated pAM37 (Table 1). A 1.1-kb HindIII-HindIII DNA fragment from pAM37, named PR37 (Table 1), was used to probe the 845 clones from the previously described genomic library of $X$. albilineans strain Xa23R1 (Rott et al. 1996). Eight new cosmids hybridized to this probe and restored albicidin production in mutant XaAM37. One of these cosmids, pALB389, carrying an insert of approximately $37 \mathrm{~kb}$ (Table 1), was used for complementation studies of the five mutants not complemented by pALB540 and pALB571. A 3-kb EcoRI-EcoRI DNA fragment from pALB389 that hybridized with probe PR37 was subcloned into pUFR043 (Table 1), and the resulting plasmid pAC389.1 was used for complementation studies. The 7-kb
EcoRI fragment carrying $\operatorname{Tn} 5$ and flanking sequence from strain XaAM10 was cloned in pBluescript II KS (+), and the resulting plasmid was designated pAM10 (Table 1). The sequence between the EcoRI site and the Tn5 insertional site of mutants XaAM10 and XaAM37 was sequenced from pAM10 and pAM37, respectively. The double-stranded nucleotide sequence of 2,986 bp containing XALB2 was deposited with GenBank (accession number AJ586577).

\section{Sequencing of the Tn5 insertional site of each $\mathrm{Tox}^{-}$mutant.}

The Tn5 insertional site of each Tox $^{-}$mutant was sequenced from plasmids obtained following cloning in pBR325 or pBluescript II KS (+) of the EcoRI fragments carrying Tn5 and flanking sequence using the sequencing primer GUSN $\left(5^{\prime}\right.$ tgcccacaggccgtcgagt $\left.3^{\prime}\right)$ that annealed 135 bp downstream from the insertional sequence IS50L of Tn5-gus A. The sequence of the Tn5 insertional site was compared with the 55,839-bp sequence containing XALB1 and with the 2,986-bp sequence containing XALB2 in order to determine the $a l b$ gene disrupted in each Tox ${ }^{-}$mutant.

\section{LITERATURE CITED}

Admiraal, S. J., Walsh, C. T., and Khosla, C. 2001. The loading module of rifamycin synthetase is an adenylation-thiolation didomain with substrate tolerance for substituted benzoates. Biochemistry 40:6116-6123.

Albertini, A. M., Caramori, T., Scoffone, F., Scotti, C., and Galizzi, A. 1995. Sequence around the 159 degree region of the Bacillus subtilis genome: The $p k s X$ locus spans 33.6 kb. Microbiology 141:299-309.

Altschul, S. F., Madden, T. L., Schäffer, A. A., Zhang, J., Zhang, Z., Miller, W., and Lipman, D. J. 1997. Gapped BLAST and PSI-BLAST: A new generation of protein data base search programs. Nucleic Acids Res. 25:3389-3402.

August, P. R., Tang, L., Yoon, Y. J., Ning, S., Muller, R., Yu, T. W., Taylor, M., Hoffmann, D., Kim, C. G., Zhang, X., Hutchinson, C. R., and Floss, H. G. 1998. Biosynthesis of the ansamycin antibiotic rifamycin: Deductions from the molecular analysis of the rif biosynthetic gene cluster of Amycolatopsis mediterranei S699. Chem. Biol. 5:69-79.

Birch, R. G. 2001. Xanthomonas albilineans and the antipathogenesis approach to disease control. Mol. Plant Pathol. 2:1-11.

Birch, R. G., and Patil, S. S. 1983. The relation of blocked chloroplast differentiation to sugarcane leaf scald disease. Phytopathology 73:13681374.

Birch, R. G., and Patil, S. S. 1985a. June 1985. Antibiotic and process for the production thereof. U. S. patent 4,525,354.

Birch, R. G., and Patil, S. S. 1985b. Preliminary characterization of an antibiotic produced by Xanthomonas albilineans which inhibits DNA synthesis in Escherichia coli. J. Gen. Microbiol. 131:1069-1075.

Birch, R. G., and Patil, S. S. 1987a. Correlation between albicidin production and chlorosis induction by Xanthomonas albilineans, the sugarcane leaf scald pathogen. Physiol. Mol. Plant Pathol. 30:199-206.

Birch, R. G., and Patil, S. S. 1987b. Evidence that an albicidin-like phytotoxin induces chlorosis in sugarcane leaf scald disease by blocking plastid DNA replication. Mol. Plant Pathol. 30:207-214.

Brady, S. F., Chao, C. J., and Clardy, J. 2002. New natural product families from an environmental DNA (eDNA) gene cluster. J. Am. Chem. Soc. 124:9968-9969.

Brendel, V., and Trifonov, E. N. 1984. A computer algorithm for testing potential prokaryotic terminators. Nucleic Acids Res. 12:4411-4427.

Cane, D. E. 1997. A special thematic issue on polyketide and nonribosomal polypeptide biosynthesis. Chem. Rev. 97:2463-2706.

Cane, D. E., and Walsh, C. T. 1999. The parallel and convergent universes of polyketide synthases and nonribosomal peptide synthetases. Chem. Biol. 6:319-325.

Cane, D. E., Walsh, C. T., and Khosla, C. 1998. Harnessing the biosynthetic code: Combinations, permutations, and mutations. Science 282:63-68.

Challis, G. L., Ravel, J., and Townsend, C. A. 2000. Predictive, structurebased model of amino acid recognition by nonribosomal peptide synthetase adenylation domains. Chem. Biol. 7:211-224.

Cheng, Y. Q., Tang, G. L., and Shen, B. 2003. Type I polyketide synthase requiring a discrete acyltransferase for polyketide biosynthesis. Proc. Natl. Acad. Sci. U.S.A. 100:3149-3154.

De Feyter, R., and Gabriel, D. W. 1991. Use of cloned DNA methylase genes to increase the frequency of transfer of foreign genes into Xan- 
thomonas campestris pv. malvacearum. J. Bacteriol. 173:336-342.

Du, L., Sanchez, C., Chen, M., Edwards, D. J., and Shen, B. 2000. The biosynthetic gene cluster for the antitumor drug bleomycin from Streptomyces verticillus ATCC15003 supporting functional interactions between nonribosomal peptide synthetases and a polyketide synthase. Chem. Biol. 7:623-642.

Du, L., and Shen, B. 2001. Biosynthesis of hybrid peptide-polyketide natural products. Curr. Opin. Drug Discovery Dev. 4:215-218.

Duitman, E. H., Hamoen, L. W., Rembold, M., Venema, G., Seitz, H., Saenger, W., Bernhard, F., Reinhardt, R., Schmidt, M., Ullrich, C., Stein, T., Leenders, F., and Vater, J. 1999. The mycosubtilin synthetase of Bacillus subtilis ATCC6633: A multifunctional hybrid between a peptide synthetase, an amino transferase, and a fatty acid synthase. Proc. Natl. Acad. Sci. U.S.A. 96:13294-13299.

Gabriel, D. W., and De Feyter, R. 1992. RFLP analyses and gene tagging for bacterial identification and taxonomy. Pages 51-66 in: Molecular Plant Pathology, Volume II: A Practical Approach. S. J. Gurr, M. J. McPherson, and D. J. Bowles, eds. IRL Press, Oxford.

Guenzi, E., Galli, G., Grgurina, I., Gross, D. C., and Grandi, G. 1998. Characterization of the syringomycin synthetase gene cluster. A link between prokaryotic and eukaryotic peptide synthetases. J. Biol. Chem. 273:32857-32863.

Huang, G., Zhang, L., and Birch, R. G. 2000a Analysis of the genes flanking $x a b B$ : A methyltransferase gene is involved in albicidin biosynthesis in Xanthomonas albilineans. Gene 255:327-333.

Huang, G., Zhang, L., and Birch, R. G. 2000b. Albicidin antibiotic and phytotoxin biosynthesis in Xanthomonas albilineans requires a phosphopantetheinyl transferase gene. Gene 258:193-199.

Huang, G., Zhang, L., and Birch, R. G. 2001. A multifunctional polyketide-peptide synthetase essential for albicidin biosynthesis in Xanthomonas albilineans. Microbiology 147:631-642.

Konz, D., Klens, A., Schorgendorfer, K., and Marahiel, M. A. 1997. The bacitracin biosynthesis operon of Bacillus licheniformis ATCC10716: Molecular characterization of three multi-modular peptide synthetase. Chem. Biol. 4:927-937.

Leong, S. A., Ditta, G. S., and Helinski, D. R. 1982. Heme biosynthesis in Rhizobium: Identification of a cloned gene coding for aminolevulinic acid synthetase from Rhizobium meliloti. J. Biol. Chem. 257:87248730 .

Marahiel, M. A., Stachelhaus, T., and Mootz, H. D. 1997. Modular peptide synthetases involved in nonribosomal peptide synthesis. Chem. Rev. 97:2651-2673.

May, J. J., Kessler, N., Marahiel, M. A., and Stubbs, M. T. 2002. Crystal structure of DhbE, an archetype for aryl acid activating domains of modular nonribosomal peptide synthetases. Proc. Natl. Acad. Sci. U.S.A. 99:12120-12125.

Mayorga, M. E., and Timberlake, W. E. 1992. The developmentally regulated Aspergillus nidulans $w A$ gene encodes a polypeptide homologous to polyketide and fatty acid synthases. Mol. Gen. Genet. 235:205-212.

Paitan, Y., Orr, E., Ron, E. Z., and Rosenberg, E. 1999. Genetic and functional analysis of genes required for the post-modification of the polyketide antibiotic TA of Myxococcus xanthus. Microbiology 145:30593067.

Piel, J. 2002. A polyketide synthase-peptide synthetase gene cluster from an uncultured bacterial symbiont of Paederus beetles. Proc. Natl. Acad. Sci. U.S.A. 99:14002-14007.

Ricaud, C., and Ryan, C. C. 1989. Leaf scald. Pages 39-58 in: Diseases of Sugarcane: Major Diseases. C. Ricaud, B. T. Egan, A. G. Gillaspie, Jr., and C. G. Hughes, eds. Elsevier Science Publishers B.V., Amsterdam.

Rott, P., Abel, M. Soupa, D., Feldmann, P., and Letourmy, P. 1994. Popu- lation dynamics of Xanthomonas albilineans in sugarcane plants as determined with an antibiotic resistant mutant. Plant Dis. 78:241-247.

Rott, P. C., Costet, L., Davis, M. J., Frutos, R., and Gabriel D. W. 1996. At least two separate gene clusters are involved in albicidin production by Xanthomonas albilineans. J. Bacteriol. 178:4590-4596.

Rott, P., and Davis, M. J. 2000. Leaf scald. Pages 38-44 in: A Guide to Sugarcane Diseases. P. Rott, R. A. Bailey, J. C. Comstock, B. J. Croft, and A. S. Saumtally, eds. Cirad/Issct, Montpellier, France.

Sambrook, J., Fritsch, E. F., and Maniatis, T. 1989. Molecular Cloning: A Laboratory Manual. 2nd ed. Cold Spring Harbor Laboratory Press, Cold Spring Harbor, NY, U.S.A.

Sanger, F., Nicklen, S., and Coulson, A. R. 1977. DNA sequencing with chain-terminating inhibitors. Proc. Natl. Acad. Sci. U.S.A. 74:54635467.

Scholz-Schroeder, B. K., Soule, J. D., and Gross D. C. 2003. The sypA, sypB, and syp $C$ synthetase genes encode twenty-two modules involved in the nonribosomal peptide synthesis of syringopeptin by Pseudomonas syringae pv. syringae strain B301D. Mol. Plant-Microbe Interact. 16:271-280.

Scholz-Schroeder, B. K., Soule, J. D., Lu, S. E., Grgurina, I., and Gross D. C. 2001. A physical map of the syringomycin and syringopeptin gene clusters localized to an approximately $145-\mathrm{kb}$ DNA region of Pseudomonas syringae pv. syringae strain B301D. Mol. Plant-Microbe Interact. 14:1426-1435.

Stachelhaus, T., Mootz, H. D., and Marahiel, M. A. 1999. The specificityconferring code of adenylation domains in nonribosomal peptide synthetases. Chem. Biol. 6:493-505

Stahl, E., ed. 1969. Pages 8555-8909 in: Thin-Layer Chromatography. 2nd ed. Springer-Verlag, New York.

Takano, Y., Kubo, Y., Shimizu, K., Mise, K., Okuno, T., and Furusawa, I. 1995. Structural analysis of PKS1, a polyketide synthase gene involved in melanin biosynthesis in Colletotrichum lagenarium. Mol. Gen. Genet. 249:162-167.

von Döhren, H., Dieckmann, R., and Pavela-Vrancic, M. 1999. The nonribosomal code. Chem. Biol. 6:273-279.

Wall, M. K., and Birch, R. G. 1997. Genes for albicidin biosynthesis and resistance span at least $69 \mathrm{~kb}$ in the genome of Xanthomonas albilineans. Lett. Appl. Microbiol. 24:256-260.

Yu, J. H., and Leonard, T. J. 1995. Sterigmatocystin biosynthesis in Aspergillus nidulans requires a novel type I polyketide synthase. J. Bacteriol. 177:4792-4800.

Yu, S., Fiss, E., and Jacobs, W. R. 1998. Analysis of the exochelin locus in Mycobacterium smegmatis: Biosynthesis genes have homology with genes of the peptide synthetase family. J. Bacteriol. 180:4676-4685.

Zhang, L., and Birch, R. G. 1997. The gene for albicidin detoxification from Pantoea dispersa encodes an esterase and attenuates pathogenicity of Xanthomonas albilineans to sugarcane. Proc. Natl. Acad. Sci. U.S.A. 94:9984-9989.

Zhang, L., Xu, J., and Birch, R. G. 1999. Engineered detoxification confers resistance against a pathogenic bacterium. Nat. Biotechnol. 17:1021-1024.

Zhu, G., LaGier, M. J., Stejskal, F., Millership, J. J., Cai, X., and Keithly, J. S. 2002. Cryptosporidium parvum: The first protist known to encode a putative polyketide synthase. Gene 298:79-89.

\section{AUTHOR-RECOMMENDED INTERNET RESOURCES}

Challis and associates' NRPS prediction blast server: jhunix.hcf.jhu.edu/ $\sim \mathrm{ravel} / \mathrm{nrps} / /$

National Center for Biotechnology website: www.ncbi.nlm.nih.gov/ 